\title{
The Political Economy of Financial Development
}

\author{
Sourafel Girma \\ and \\ Anja Shortland
}

\section{Draft, please do not cite}

\begin{abstract}
Political economy theories of financial development argue that in countries where a narrow elite controls political decisions, financial development may be obstructed to deny access to finance to potential competitors. We use panel data on developed and developing countries from 1975-2000 to examine this hypothesis, as well as looking at the effect of regime transitions on financial development. Our results show that the degree of democracy and political stability explain differences in the speed of financial development and that including these regime characteristics makes legal origin variables obsolete.
\end{abstract}

\section{1: Introduction}

The economic literature studying the effect of financial development on growth has provided ample evidence that financial development has a positive effect on long-run economic growth. ${ }^{1}$ Establishing well-functioning financial markets and financial institutions, which attract savings and channel them to productive investment projects, should therefore be a policy priority for governments. In recent years the research agenda has turned to the question of why many countries nevertheless remain financially underdeveloped.

\footnotetext{
${ }^{1}$ See Levine (2003) and Demetriades and Andrianova (2004) for excellent recent overviews of the literature.
} 
There are a number of potential explanations for and empirical studies of why financial development has been slow in a large number of countries. The research broadly falls into three interrelated groups. The first group stresses that financial institutions do not succeed in an institutional vacuum, but need a legal and regulatory environment in which contracts can be enforced and bankers are given strong incentives to behave honestly. ${ }^{2}$ The second group looks at the links between law and finance, showing that specific types of legal system are more conducive to protecting investor rights and adapting the law to take into account financial innovations. ${ }^{3}$ The third group looks at the political economy of financial development arguing that financial underdevelopment may be the outcome of political circumstances protecting the interests of a narrow political / industrial elite. ${ }^{4}$ Such an elite may have little interest in developing well-functioning capital markets, as they are served well by relationship banking and the absence of arms' length finance restricts potential competitors' access to finance.

This paper aims to contribute to the second and third of these arguments by empirically evaluating the influence of the political system on financial development. For this we study the effect of political variables, which capture the degree to which a narrow elite controls the levers of power and the level of regime stability on the change in financial development. We use panel data of developed and developing countries from 1975 to 2000 . We study a number of different aspects of financial development. We control for legal origin as well as for exogenous factors driving financial development and test whether the importance of political institutions differs between legal systems and different time periods.

Our results show that both the degree of democracy in the political system and the stability of the political system have statistically significant effects on the annual change in financial development. To the extent that democracy restricts the influence of elite groups and lobbies by widening political participation, our results provide evidence for the Rajan and Zingales (2003) proposition that political systems governed by narrow elites obstruct the development of the financial system.

\footnotetext{
2 e.g. Kaufmann et al (1999), Demirguec-Kunt and Detragiache (1998), Andrianova et al (2003)

${ }^{3}$ La Porta et al $(1997,1998)$, see Beck et al (2001a) for a review

${ }^{4}$ Rajan and Zingales (2003)
} 
Controlling for political regime characteristics directly makes legal origin indicators obsolete and provides an important addition to the "settler mortality hypothesis", which argues that development is shaped by colonisation strategies. ${ }^{5}$

The paper is organised as follows: Section 2 presents a brief review of the literature and section 3 describes the data used. The methodology is discussed in section 4 and results are presented and discussed in section 5. Section 6 concludes.

\section{2: Literature Review}

The theoretical literature predicts that financial development is a positive function of real income and the real interest rate. ${ }^{6}$ Financial markets promote investment through debt intermediation and hence generate economic growth. Economic development in turn creates demand for finance, so the likely causal effect between financial development and economic growth is bi-directional. ${ }^{7}$ A positive real interest rate increases the volume of savings, increasing financial depth and at the same time improves the average productivity of capital by making investment in low return projects unattractive; this in turn boosts growth. ${ }^{8}$ More recently, however, academic inquiry has turned to explanations of why in some countries the virtuous cycle of economic and financial development is slow to take off.

\section{Institutional underdevelopment}

Economic development in general and financial development in particular relies on good governance. ${ }^{9}$ Financial systems need to be regulated and supervised to ensure that saver confidence is not undermined by bank failures and that savings are channelled to the most productive investments rather than into the pockets of connected individuals, or gambled away on high-risk projects. ${ }^{10}$ The empirical relationship between financial liberalisation and financial crises depends strongly on a

\footnotetext{
${ }^{5}$ Acemoglu (2001), Beck et al (2003a), discussed in detail below.

${ }^{6}$ McKinnon (1973), Shaw (1973)

${ }^{7}$ Demetriades and Hussein (1996)

${ }^{8}$ Fry (1997)

${ }^{9}$ Kaufmann et al (1999), Hellmann et al (2000), Akerlof and Romer (1993)

${ }^{10}$ Hellmann et al (2000), also see Perotti (2001) on the case of Russia
} 
country's institutional environment. ${ }^{11}$ Respect for the rule of law, a low level of corruption and good contract enforcement are crucial for the efficient functioning of a financial system. This literature therefore argues that booms and busts in the financial sector and the resulting financial underdevelopment are due to governments' inability to address institutional shortcomings or a lack of understanding of the foundations of a sound financial system and hence badly sequenced reforms.

\section{Legal and institutional heritage}

The literature on Law and Finance, however, points to a more fundamental problem: some legal systems are not well suited to creating the preconditions for the successful development of financial systems and institutions. ${ }^{12}$ Financial development (especially arms' length finance) depends on enforcement of outsiders' property rights. The "static" view of law and finance looks at differences in legal traditions regarding the comparative rights of individual investors vis-à-vis the state. Common law systems were designed to protect investor property against the Crown, creating systems in which individuals transact confidently. Civil law on the other hand sets the state above the courts and therefore the interests of politically connected heads of firms above individual investors. ${ }^{13}$

The "dynamic" view of law and finance looks at the adaptability of law to changing conditions, giving flexible legal systems an advantage in fostering financial development. ${ }^{14}$ Common law emerges on a case-by-case basis, so the gap between an economy's needs and the law is quickly closed. On the other extreme is the immutable legal code of French civil law (though in practice French law has not been static). The more hurdles there are to legal reform, the less investor protection there is at the cutting edge of financial innovation, tending to slow down financial development.

There are two main critiques of this literature. Firstly some civil law countries performed very well in terms of financial development in the early $20^{\text {th }}$ century. ${ }^{15}$ The

\footnotetext{
${ }^{11}$ Demirguec-Kunt and Detragiache (1998)

${ }^{12}$ See Beck et al (2001a) for a review of the literature

${ }^{13}$ La Porta et al $(1997,1998)$

${ }^{14}$ Beck et al (2001b)

15 e.g France, Germany, Argentina and Russia
} 
disadvantages of civil law only appear when studying countries after $1970 .{ }^{16}$ Secondly there is as large a discrepancy in terms of financial development within as between legal origins. British legal origin does not appear to have been a panacea for Nigeria, Pakistan and Zimbabwe, while Luxembourg, Belgium and the Netherlands do not appear particularly encumbered by their French legal origin.

One way in which the second puzzle of diverging performance within legal origin groups has been addressed is to pay attention to the colonisation strategy employed in different countries. Acemoglu (2001) argues that in countries with high mortality rates for European colonisers, institutions were set up to allow a small elite to extract precious raw materials. ${ }^{17}$ When the colonisers left, post-colonial elites took over the same institutions to continue to extract surpluses. In more benign climates, Europeans settled and established institutions to protect long-run economic interests. ${ }^{18}$ Once a particular system has been set up, it advantages the interest groups benefiting from the system within the political process. Hence even inefficient systems are perpetuated; there is "path dependence". ${ }^{19}$ The "settler mortality" hypothesis has been directly applied to financial development in Beck et al (2003), providing empirical evidence that the institutional endowment matters.

\section{Political economy}

Another way of looking at the divergent performance of countries with similar legal systems over time is to look at the political system in which decisions about economic policies are made. North (1990) and Olson (1993) argue that those in power shape policies and institutions to stay in power and enrich themselves. Financial underdevelopment may therefore be a deliberate policy choice by incumbents. An established military / industrial elite may be advantaged in a system in which entry of new firms is restricted through limited access to financial capital by outsiders. For well-connected and well-capitalised firms access to finance would be available through a system of relationship banking, regardless of disclosure standards and contract enforcement. ${ }^{20}$ At best, therefore there is no political pressure for the

\footnotetext{
${ }^{16}$ Rajan and Zingales (2003)

${ }^{17}$ E.g. Tropical Africa

${ }^{18}$ E.g. Australia, New Zealand, the US

${ }^{19}$ Bebchuk and Roe (1999); Acemoglu (2001), Zanella et al (2003)

${ }^{20}$ Rajan and Zingales (2003)
} 
development of arms' length finance leading to a policy of neglect regarding institutional fundamentals. At worst the development of financial markets could be actively sabotaged through state control over the financial sector. ${ }^{21}$

The political economy literature is therefore linked to the previous explanations of legal endowments and institutional underdevelopment. Countries in which extractive institutions were set up by colonial powers to avoid large-scale permanent settlement have often continued to privilege small elites. These post-colonial elites have continued to restrict suffrage in the political system and have limited access to economic resources to those within their own group. ${ }^{22}$ In such systems there are no incentives to put into place a legal system that protects individuals' rights against the state, to protect property rights and create regulatory and supervisory institutions - i.e. to create the institutional preconditions for successful financial development.

A first test of a political economy model of financial development was undertaken by Rajan and Zingales (2003). Their paper tests the hypothesis that during times of high international capital mobility and in countries with a high degree of trade openness there would be higher levels of financial development: Capital mobility and open trade undermine both the ability and the incentive of incumbents to suppress domestic financial development. Under conditions of trade openness incumbents need investment finance to remain competitive, while periods of high international capital flows offer incumbent firms the option to tap international financial markets. They show that the exogenous component of a country's trade as well as an interaction term between trade openness and international capital mobility have a significant and positive effect on financial development over the $20^{\text {th }}$ century. ${ }^{23}$

However, this methodology does not directly address the question of the importance of the domestic political system in financial development. There are no variables describing the political regime characteristics directly. Therefore the focus of this paper is the effect of domestic regime characteristics on the speed of financial

\footnotetext{
${ }^{21}$ La Porta et al (2001), also see the literature on state ownership of banks

${ }^{22}$ Aided in this perhaps by a civil law system that favours centralisation of power.

${ }^{23}$ Both trade and financial openness variables are chosen to be exogenous to the political process: the decision to open trade and capital flows is in itself political. The trade openness proxy is based on a
} 
development. We firstly examine the effect of the extent to which political system restricts suffrage. In autocratic regimes the interests of a narrow elite consisting of those holding capital in labour-rich economies (and especially the owners of statesponsored "infant industries") may prevail against the interests of labour, the unemployed and potential new entrants. Therefore the more concentrated power and the more non-democratic the system, the more likely it is, that a small industrial elite of the type described by Rajan and Zingales (2003) can use its control over policymaking to restrict financial development. Secondly we aim to capture the effect of political instability on financial development. We would expect a negative effect from major changes in the polity, as social capital is destroyed.

\section{3: Data}

The focus of this paper is on the factors that facilitate, restrict or reverse financial development. The aspect of financial development we are most interested in from a political economy point of view is how easy it is for any investor (not just the wellconnected ones) to obtain finance for investment projects. That is we are looking for indicators of "arms-length finance". We look at three indicators of financial development:

- Private sector credit $/ \mathrm{GDP}^{24}$

- Stock market capitalisation / GDP

- Total stock market value traded / GDP ${ }^{25}$

We would expect the strongest results for stock market development, as bank lending can be relationship-based, preserving elite control over finance. Higher-level institutional requirements need to be in place for stock market to function effectively and be trusted by small investors. We use the database of financial development from Beck et al (2003b), noting that there is a limited data-set for the stock market capitalisation and trade ratio: ${ }^{26}$

country's size and proximity to trade partners or purely on population size. Capital flows are measured at the systemic level.

${ }^{24}$ We do not want to capture financial flows to state-owned enterprises controlled by the elite.

${ }^{25}$ This measure of stock market liquidity distinguishes between stock markets in which there is a large degree of government involvement and those in which trading is active, encouraging small investor participation.

${ }^{26}$ Data are available from 1975 at best, which determines the starting date for the regression analysis. Data availability for the banking sector is in general much better than for stock markets. The data 
We include lagged GDP growth as an independent variable to capture the effect of increased demand for financial services, in line with the theoretical literature on financial development discussed above. However, we omit the real interest rate from the reported regressions. Firstly whether the real interest rate is positive or negative is partially a political decision, linked to a policy of financial liberalisation. Secondly, data availability on the real interest rate is patchy, reducing our sample by one quarter on the banking sector variables and one-fifth on the stock market capitalisation variable, with missing entries concentrated among the more autocratic, less-developed countries. $^{27}$

To proxy for the extent of incumbent power we use the "combined polity score" polity $2^{28}$ - as measured by the Polity IV database (Marshall et al 2003). ${ }^{29}$ The Polity variable was designed to record the regime's institutionalized authority characteristics. Firstly, the database records a democracy score (ranging from 0 to 10) for each country, based on the openness of the political process (i.e. the extent to which citizens can effectively express preferences about policies and leaders through elections) and the degree of restraints on the powers of the chief executive. The maximum score would be allocated to a democracy in which the executive is chosen in free and fair elections with universal suffrage and there are substantial checks and balances constraining the chief executive's power. ${ }^{30}$ Secondly each country has an autocracy score (again ranging from 0 to 10) based on how political leaders are selected (e.g. by designation or chosen from closed lists), the constraints on their powers and the regulation and competitiveness of political participation. ${ }^{31}$ Polities may have mixed authority traits and can have intermediate scores on both the

availability for indicators of the development of the bond markets in the Beck et al (2003) database is too poor for the purpose of this analysis.

${ }^{27}$ If the real interest rate is included in the regressions it has the expected positive effect on financial development, however, it is only statistically significant in outlier-robust regressions.

${ }^{28}$ Polity2 imputes normal ranges of polity scores for special polity conditions such as periods of transition and periods of collapse of the central authority. State failures due to occupations are left blank.

${ }^{29}$ See Polity IV project Data-set Users Manual

${ }^{30}$ The scale therefore discriminates between developed democratic systems on the basis of their limitation on the powers of the chief executive, for example France's democracy score increases with the onset of "cohabitation" during the Mitterrand presidency.

${ }^{31}$ Regulation refers to who participates in the political process (has the right to vote), competitiveness to whether the opposition is suppressed (single party states) or restricted. 
democracy and authority scores. ${ }^{32}$ Subtracting the autocracy score from the democracy score of a country creates the polity2 variable. Higher scores of polity2 therefore indicate a higher degree of democracy.

An incumbent elite is more likely to be able to block financial development by impeding reforms in more authoritarian systems, as opposition demands for more equal access to resources can be ignored. ${ }^{33}$ In democracies the influence of lobbies is reduced through systems of checks and balances, as they increase the number of vetoplayers that have to be bribed. The polity2 variable therefore appears to be a reasonable proxy of elite control over policies that advance or hinder financial development. We also experimented with concentration of power within the legislative as recorded by Beck et al (2001c) as an alternative proxy for elite control over the economy. ${ }^{34}$

We do not include direct indicators of institutional quality (such as rule of law, corruption, government effectiveness and transparency) in our regressions, as these in part reflect political regime characteristics: in more democratic systems corrupt and ineffective politicians are voted out of power. However, we include an indicator of political instability to reflect that financial development requires a certain level of social development, trust and reputation. Upheaval in the political system results in the loss of human and social capital, uncertainty and the breakdown of long-term economic relationships. Fear of confiscation due to frequent regime changes leads people to hold physical assets instead of financial assets. We use the number of years that have elapsed since a major regime transition, either a move towards democracy, a major clamp-down on civil rights or the foundation or independence of a state: the variable "durable" from Polity IV. We use the durability variable from the 2003 version of the database, in which durability has been re-calculated and extended back to the beginning of the data series. It now correctly displays state failure through

\footnotetext{
${ }^{32}$ For example South Africa in the 1980s has a democracy score of 7 and an autocracy score of 3 , reflecting that within a relatively democratic system political participation was restricted to white South Africans.

${ }^{33}$ Acemoglu (2003), Pagano and Volpin (2003)

${ }^{34}$ Herfindahl index: the Herfindahl index increases in the concentration of power within parliament with the highest score going to single-party states. This proxy again reflects the competitiveness of elections on the one hand and the restrictions on the power of the executive. The regression results are extremely similar to the ones using the polity2 indicator and are available upon request.
} 
occupation in continental Europe in the 1940s. Table 1a provides some summary statistics of the changes in the financial development indicators and the level of political variables employed in the paper. The countries with the fastest financial development are considerably more democratic and stable than the median, while those countries that experience financial disintermediation are on average highly autocratic and /or have unstable regimes.

We control for trade openness as suggested by Rajan and Zingales (2003), again noting that a country's actual openness is partly endogenous to the political process. Therefore we prefer to use the exogenous component of trade determined by economic geographical factors rather than actual openness. Gravity models of trade argue that bilateral trade flows are a log-linear function of the sizes of and the distance between trading partners. ${ }^{35}$ Small nations are less self-sufficient and are therefore predisposed towards greater openness. Frankel and Romer (1999) constructed measures of the geographic component of countries' trade based on: size (log area and $\log$ economically active population), distances from other countries (great circle distances between principal cities), whether they share a border and whether they are landlocked, plus some interaction terms. The reported estimate of the geographic component of a country's trade is the sum of the estimated geographic components of its bilateral trade with each other country in the world. Data are available for 150 countries in the early $1990 \mathrm{~s}^{36}$

In the Rajan and Zingales (2003) paper the international capital mobility is measured at the level of the international system. ${ }^{37}$ This is again to avoid the problem that actual capital mobility is a political choice- certain types of governments are more likely to liberalise capital flows. ${ }^{38}$ In this paper, changes in international capital mobility, which affect all countries simultaneously, are captured through time and period dummies ${ }^{39}$.

\footnotetext{
${ }^{35}$ Linnemann (1966)

${ }^{36}$ As the data are based on geography alone, there is no variation from $1975-2000$, except Ethiopia, and Germany (and some post-Soviet states, which in any case have no data availability before the early 1990s).

${ }^{37}$ Proxied by the "mean absolute value of current account / GDP over five-year periods for a sample of 14 developed countries." From Taylor (1998)

${ }^{38}$ e.g. Alesina et al (1994), Haggard and Maxfield (1996), Li and Smith (2003)

${ }^{39}$ Period $1=1976-1980$, period $2=1981-1985$, period $3=1986-1990$, period $4=1991-1995$, period 5

= 1996-2000
} 
We control for the origin of a country's legal system. We augmented the data presented in La Porta et al (1998) from CIA World Factbook entry for the legal system. We excluded countries with entries that did not fit neatly into the five original legal origin categories and introduced a new category for post-Socialist civil law codes from 1990 for the same reason. ${ }^{40}$ We report results using a civil law dummy grouping the German, French, Scandinavian and post-Socialist civil law countries together, as there appears to be no difference between the different civil law countries.

Finally we control for whether a country has recently experienced a banking crisis. Widespread public loss of confidence may result in a discontinuity in financial development. We cannot use the contemporary banking crisis dummy as the definition of banking crises contains "widespread bank runs" - in turn linked to the contraction of the deposit base, which is one of the dependent variables. ${ }^{41} \mathrm{We}$ therefore use a lagged dummy taken from data in Caprio and Klingebiel (2003) and Glick and Hutchinson (1999).

Table $1 \mathrm{~b}$ provides preliminary evidence in favour of the hypotheses outlined above in the form of correlation coefficients between the variables. A higher democracy score is positively correlated with all proxies for the speed of financial development, with the expected negative correlation between concentration of power and financial development. Greater regime stability has positive effects on financial development, as has intrinsic openness to trade. Bank crises have negative effects on financial development, while lagged growth has a positive effect on the banking sector variables and a negative effect on the stock market.

\section{4: Methodology}

We perform the regressions using annual data from 1975-2000 in so far that they are available. Three variants of each model are estimated: (i) and (iv) the effect of the

\footnotetext{
${ }^{40}$ Examples are "Roman-Dutch law" (e.g. Namibia / Botswana) and "Mixture of French and British Law" (e.g. Mauritius, Vanuatu)

${ }^{41}$ Bank runs are explicitly included in the definition of banking crises in Demirguec-Kunt and Detragiache (1997), Lindgren, Garcia and Saal (1996), Kaminsky and Reinhart (1999)
} 
political variable (polity2) is assumed to be the same across all periods and countries (ii) and (v) the effect of polity2 is allowed to vary by legal origin of the countries in the sample and (iii) and (vi) the effect of polity2 is allowed to vary across periods.

\section{Regression equations}

Firstly we look at short-run financial development:

$\Delta \mathrm{FD}_{\mathrm{it}}=\beta_{0}+\beta_{1}$ elite $_{\mathrm{it}}+\beta_{2}$ stability $_{\mathrm{it}}+\beta_{3}$ openness $_{\mathrm{i}}+\beta_{4}$ legal origin $_{\mathrm{i}}+\beta_{5}$ financial crisis $_{\mathrm{it}-1}+\beta_{6}$ GDPgrowth $_{\mathrm{it}-1}+\beta_{7-32}$ time dummies $+\varepsilon_{\mathrm{it}}$

$\Delta \mathrm{FD}_{\mathrm{it}}=\beta_{0}+\beta_{1}$ elite $_{\mathrm{it}}+\beta_{2}$ elite $_{\mathrm{it}}{ }^{*}$ legal origin $_{\mathrm{i}}+\beta_{3}$ stability $_{\mathrm{it}}+\beta_{4}$ openness $_{\mathrm{i}}+\beta_{5}$ legal origin $_{\mathrm{i}}+\beta_{6}$ financial crisis $_{\mathrm{it}-1}+\beta_{7}$ GDPgrowth $_{\mathrm{it}-1}+\beta_{8-33}$ time dummies $+\varepsilon_{\mathrm{it}}$

$\Delta \mathrm{FD}_{\mathrm{it}}=\beta_{0}+\beta_{1}$ elite $_{\mathrm{it}}+\beta_{2}$ elite $_{\mathrm{it}}{ }^{*}$ period dummies $+\beta_{3}$ stability $_{\mathrm{it}}+\beta_{4}$ openness $_{\mathrm{i}}+\beta_{5}$ legal origin ${ }_{i}+\beta_{6}$ financial crisis $_{\mathrm{it}-1}+\beta_{7}$ GDPgrowth $_{\mathrm{it}-1}+\beta_{8-33}$ time dummies $+\varepsilon_{\mathrm{it}}$

We then look at the relationship between changes in financial development and the past level of financial development:

$\Delta \mathrm{FD}_{\mathrm{it}}=\beta_{0}+\beta_{1}$ elite $_{\mathrm{it}}+\beta_{2}$ stability $_{\mathrm{it}}+\beta_{3}$ openness $_{\mathrm{i}}+\beta_{4}$ legal origin $_{\mathrm{i}}+\beta_{5}$ financial crisis $_{\mathrm{it}-1}+\beta_{6}$ GDPgrowth $_{\mathrm{it}-1}+\boldsymbol{\beta}_{7} \mathbf{F D}_{\mathrm{it-1}}+\beta_{8-33}$ time dummies $+\varepsilon_{\mathrm{it}}$

$\Delta \mathrm{FD}_{\mathrm{it}}=\beta_{0}+\beta_{1}$ elite $_{i \mathrm{it}}+\beta_{2}$ elite $_{\mathrm{it}}{ }^{*}$ legal origin $_{\mathrm{i}}+\beta_{3}$ stability $_{\mathrm{it}}+\beta_{4}$ openness $_{\mathrm{i}}+\beta_{5}$ legal origin $_{\mathrm{i}}+\beta_{6}$ financial crisis $_{\mathrm{it}-1}+\beta_{7}$ GDPgrowth $_{\mathrm{it}-1}+\boldsymbol{\beta}_{\mathbf{8}}$ FD $_{\text {it-1 }}+\beta_{9-34}$ time dummies $+\varepsilon_{\mathrm{it}}$

$\Delta \mathrm{FD}_{\mathrm{it}}=\beta_{0}+\beta_{1}$ elite $_{\mathrm{it}}+\beta_{2}$ elite $_{\text {it }}{ }^{*}$ period dummies $+\beta_{3}$ stability $_{\mathrm{it}}+\beta_{4}$ openness $_{\mathrm{i}}+\beta_{5}$ legal origin $_{\mathrm{i}}+\beta_{6}$ financial crisis $_{\mathrm{it}-1}+\beta_{7}$ GDPgrowth $_{\mathrm{it}-1}+\boldsymbol{\beta}_{\mathbf{8}}$ FD $_{\mathrm{it-1}}+\beta_{9-34}$ time dummies $+\varepsilon_{\text {it }}$

Financial Development: We report regression results for

1) Private sector credit / GDP (credit),

2) Stock market capitalisation / GDP (smcap)

3) Stock market value traded / GDP (smtrade)

Elite: Degree of Democracy (polity) or Herfindahl index 
Stability: Durability of regime (durability)

Openness: Geographical pre-disposition to trade (trade)

Legal Origin: Socialist Law, Civil Law (dummy variables, Common Law as baseline)

For each model, three alternative estimation strategies are employed. The first is OLS with standard errors, which are robust to arbitrary heteroskedasticity and within country serial correlation. It is well known that hetereskedasticity is prevalent in cross sectional data sets and within country serial correlation is likely to be present because of unobserved country-specific heterogeneity.

A problem frequently encountered in estimation relates to outliers. The inclusion or exclusion of outliers, especially if the sample size is small, can substantially alter the results of regression analysis. If useful generalisations are to be drawn, it is thus important to ensure that the results reflect what is going on in the majority of the sample rather than being driven by a few outlying observations only. Our sample has a number of extreme outliers, both positive and negative. ${ }^{42}$ For this reason we deploy a second estimation strategy in this study: outlier robust regression (Rousseeuw and Leroy, 1987). This is essentially a three-step procedure. The first step involves estimating the regression and calculating Cook's distance measure of influence. Cook's distance (D) for the $i^{\text {th }}$ observation is a measure of the distance between the coefficient estimates when observation $\mathrm{i}$ is included and when it is not, and it is defined as

$$
D_{i}=\frac{\hat{e}_{s i}^{2}\left(s_{p i} / s_{r i}\right)^{2}}{k}
$$

where $\hat{e}_{s i}$ refers to standardised residuals, $s_{r i}$ to standard error of the residuals and $S_{p i}$ to standard error of prediction. $k$ represents the number of independent variables including the intercept term.

High values of Cook's D imply that the ith observation has significant influence on estimation results, therefore, can be deemed to be an outlier. The second step in robust regressions is to screen data points in search of such outliers and

\footnotetext{
${ }^{42}$ See diagrams $1-3$
} 
eliminates observations for which Cook's distance exceeds 1 - these are the gross outliers. Thereafter, robust regression involves an iterative weighted least squares method whereby outliers are identified and weights are assigned.

The two estimation procedures outlined above (i.e. OLS and outlier robust regressions) assume that the political variables are exogenous to the model determining the growth of financial development. In the course of our empirical investigation we have relaxed this assumption and employ a generalised method of moments (GMM) procedure due to Hansen (1982). To this end twice lagged values of the polity2 variable interacted with the legal origin dummies are used as instrumental variable candidates. We are careful to check the appropriateness of the instrumental variable candidates in two respects. First, their validity in the sense of having no correlation with the equation error is formally tested with the aid of Hansen's (1982) test for overidentifying restrictions (which is the robust version of the classical Sargan test statistic). Second, we ascertain that they are relevant in that they exhibit sufficiently strong correlation with the potentially endogenous regressor (i.e. polity2). It has been noted in the econometric literature that when the partial correlation between the instruments and the endogenous variable is low, instrumental variables regression is biased in the direction of OLS estimator (see e.g. Staiger and Stock, 1997). Staiger and Stock (1997) recommend that the F-statistics ${ }^{43}$ (or the partial Rsquare values) from the first-stage regression be routinely reported in applied work. A high partial R-squared of the excluded instruments or a large F-statistic suggests the instruments are relevant, instrumental variable or GMM estimates are reliable in finite samples. By contrast, when the F-statistic is small or the partial R-square value is low, inference based on instrumental variable estimates would be unreliable. Reassuringly we find that our instruments are appropriate on both counts (see Table A of the appendix). A comparison of the OLS and GMM estimates via Hausman test statistics reveals that the two are not systematically different, suggesting that the assumption of exogeneity of the polity2 variable is justified. For this reason we restrict our discussion to the results obtained from the OLS and outlier-robust regressions, and the GMM estimates are relegated to the appendix

\footnotetext{
${ }^{43}$ The F-statistic tests the hypothesis that the instruments should be excluded from the first-stage regressions.
} 


\section{5: Results}

Table 2 presents results for equation (i), in which the pure polity indicator is used. The polity proxy has a positive coefficient, showing that more democratic countries tend to have faster financial development, as predicted by the political economy literature. The proxy is highly statistically significant in the banking sector regressions, but insignificant in 3 out of the four stock market regressions. The second political regime proxy, durability, has a positive coefficient: countries, which have not experienced a major regime transition for a long time tend to have faster financial development than those, which have more recently gone through major upheaval. Durability is statistically significant in all regression specifications. A civil law system appears to be a statistically significant explanatory variable for stock market capitalisation in the outlier robust regression, but with an unexpected positive coefficient. Otherwise civil law is not significant, once political regime characteristics are controlled for. ${ }^{44}$ Socialist legal origin on the other hand enters as a significant variable with an unexpected positive coefficient. ${ }^{45}$ Of the control variables the lagged banking crisis has the expected negative effect in 5 out of 6 specifications, significant at least at the 5\% level. Lagged GDP growth appears to have the expected positive effect on the banking system variable (significant at the $1 \%$ level), but none on stock market development. Finally there is some evidence that countries naturally more open to trade have faster banking sector development, while there may be negative effects on the stock market.

Table 3 presents results for the polity indicator interacted with the legal origin categories (regression ii). The polity proxy again has the expected positive coefficient in all regressions, but is only significant for three of the regressions. The interaction term between polity and civil law is only significant (and negative) in one regression specification. The significant, but mostly negative coefficient of the polity score interacted with Socialist legal origin is likely to be driven by the recent good performance of the Chinese economy despite its closed political system. The

\footnotetext{
${ }^{44}$ When the legal origins are separated into French, German, Scandinavian and Post-Socialist none is statistically significant, so for brevity the variables are summarised in one dummy.

${ }^{45}$ However, these results are based on a very narrow set of data, with only China reporting on its burgeoning stock market in the 1990s and the banking sector observations based on observations from Poland, Hungary in the 1980s and China in the 1990s.
} 
durability proxy is again statistically significant and positive. Banking crises have statistically significant negative effects in 5 out of the 6 regressions. Again predisposition to trading and lagged GDP growth both contribute to banking sector development, with apparently negative effects on the stock market.

Table 4 looks at the effect of the degree of democracy in different time periods (regression iii). It appears that the effect of democratic governments on financial development was strongest in the period from 1996-2000, contributing to both banking sector and stock market growth. It was also positive and significant in other periods, but the evidence is less clear. Durability again has positive and generally highly significant effects on the speed of financial development. Civil law does not appear to have a clear effect on financial development. Financial crises disrupt financial development in the following year. Trade and lagged GDP growth again spur banking sector development. The effect of trade on stock market development appears to be negative, while there is no link between lagged GDP growth and stock market capitalisation and trade.

The year dummies in all three tables show a pattern of strong expansions in private sector credit in the late 1970s and early 1980s and again in 1996-1999. Stock market development was particularly strong in the mid 1990s. Given the Rajan and Zingales hypothesis that financial development is stimulated by international capital mobility, one might have expected a stronger pattern with financial development taking off after the late 1980s with capital account liberalisation in Europe and beyond.

When we include the lagged level of the financial development indicators among the explanatory variables (regressions (iv)-(vi)), it is a highly significant explanatory variable of the change in financial development in all of the outlier robust regressions. ${ }^{46}$ The positive coefficient indicates that the lagged level is picking up unobserved country effects, which raise both present and past financial development. While the signs and coefficients on the political regime variables are mostly relatively robust, significance levels tend to decline. Overall the result of the positive effects of regime durability and democracy in the late 1990s are, however, preserved. An

\footnotetext{
${ }^{46}$ Results reported in tables 5-7
} 
explanation for the decline in significance levels is the correlation between the level of financial development (credit and stock market capitalisation) and the political regime variables (shown in table 8). Multicollinearity would tend to increase the standard errors of the coefficients and hence decrease the reported significance levels.

In summary, the development of the market for private sector credit appears to be furthered in democratic systems and stable polities. The positive effect of democracy on banking sector development appears to be particularly strong in the late 1990s and does not appear to vary across legal origins. Countries intrinsically more open to trade and those experiencing faster economic growth also have faster banking sector development. Demand for finance (and trade finance in particular) appears to boost the banking sector. Banking crises have negative effects on credit growth.

Stock market development on the other hand responds positively to political stability, but the degree of democracy only appears to have mainly mattered in the late 1990s. Banking crises and a geographical predisposition to trade openness affect stock market growth negatively. There is no statistically significant positive effect of lagged GDP growth on stock market capitalisation and trade in shares, but there is some evidence that stock markets are driven by exogenous factors at the systemic level (such as capital mobility) that are picked up by the year dummies.

Given that narrow elites would be more likely to develop (potentially relationshipbased) banking than arms' length financial markets, it is surprising that the effects of the polity variables in the stock market regressions are less robust than for the banking sector. Note, however, the stock market regression results are based on a sample that is about half the sample size of the banking sector development. When looking at the sub-sample of countries in which stock market capitalisation is observed (using crosssectional time-series logit analysis) it emerges that the probability of observing stock market data rises significantly in durable and / or democratic regimes. ${ }^{47}$ The regression results on the stock market variables reported above therefore systematically under-estimate the importance of the political regime characteristics. When we include the missing observations of stock market capitalisation and trade

\footnotetext{
${ }^{47}$ See table 9
} 
ratios in the regressions and assume that the same process governs whether or not there is a stock market and how fast it grows if it does exist, we can use Panel Tobit analysis. ${ }^{48}$ Tables 10 and 11 show that when making these assumptions, the effects of both polity variables on stock market capitalisation and stock market trade are now highly statistically significant.

\section{6: Conclusions}

From our panel data analysis political regime characteristics have emerged as significant factors influencing the speed of financial development, alongside the conventional determinants of financial development stemming from arguments of demand for finance and controls for discontinuities created by financial crises. Regime durability is highly statistically significant in all specifications of the regressions and affects all aspects of financial development. A more representative political system has positive effects on affects all aspects of financial development, with the greatest and most robust effects in the late 1990s. We therefore provide empirical evidence for the arguments made in the political economy literature on financial development. More autocratic regimes representing the interests of narrow but powerful elites appear to delay and obstruct financial development. ${ }^{49}$ Once we control for the degree to which a narrow elite controls the levers of power, whether or not the legal system is based on a civil law code no longer appears to matter.

A further strong message is that political upheaval (regardless of whether this is a move towards democracy or autocracy or a state failure) is detrimental to financial development. This result provides an additional explanation for the patterns of financial development observed in Rajan and Zingales (2003) with Latin American and continental European countries seeing a strong reversal in financial development after 1913. It is possible that their financial systems were devastated by wars, occupations and revolutions, and social capital was destroyed by transitions and

\footnotetext{
${ }^{48}$ In fact a Heckmann test would be preferable, as the two processes may be quite different. However, at present we are not aware of Heckmann tests for panel data.

${ }^{49}$ This evidence is in line with the settler mortality hypothesis of financial development to the extent that political systems privileging narrow elites are perpetuated after colonisation.
} 
reforms. Financial development recovered again in times of peace, perhaps with an added impetus from international capital mobility.

The importance of the durability indicator also provides an alternative / addition to the settler mortality hypothesis to explain variations in financial development within legal origin groups. ${ }^{50}$ Very high levels of financial development are experienced in Switzerland, Britain, the US and the white Commonwealth, which enjoyed political stability in which financial development could prosper. Intermediate levels of financial development are posted by continental European countries, in which financial development was interrupted by state-failures (e.g. occupation in Belgium, France and the Netherlands) or autocratic experiments followed by democratic transitions (e.g. Spain, Greece). The lowest levels of financial development are seen in those countries with the most volatile political systems, regardless of legal origin or climatic / health conditions (e.g. Turkey, Pakistan, Nigeria, Argentina). Given the results from this analysis it would therefore be interesting to re-examine the data in Beck et al (2003a) and Rajan and Zingales (2003) in the light of the "regime stability" and "democracy" hypotheses.

\section{References}

Acemoglu, Daron (2003): The Form of Property Rights: Oligarchic vs Democratic Societies NBER Working Paper No. w10037

Acemoglu, Daron, Simon Johnson and James Robinson (2001): The Colonial Origins of Comparative Development: An Empirical investigation. American Economic Review Volume 91 \#5 pp 1369 -1401

Andrianova, Svetlana, Panicos Demetriades and Anja Shortland (2003) "State Banks, Institutions and Financial Development" Discussion Papers in Economics No 02/13, Leicester University

Akerlof George and Paul Romer (1993): Looting: The Economic Underworld of Bankruptcy for Profit Brookings Papers on Economic Activity September 1993 (2) pp1-60

Alesina, Alberto, Vittorio Grilli and Gian-Maria Milesi-Ferretti (1994): The Political Economy of Capital Controls in Leonardo Leidermann and Assaf Razin (eds)

\footnotetext{
${ }^{50}$ As studied in Beck et al (2003a).
} 
Capital Mobility: The Impact on Consumption, Investment and Growth; Cambridge University Press

Arestis Phillip and Panicos Demetriades (1997): Financial Development and Economic Growth: Assessing the Evidence Economic Journal vol 107 pp783-799

Bebchuk, Lucian and Mark Roe (1999): A Theory of Path Dependence in Corporate Governance and Ownership Columbia Law School Working Paper no 131

Beck Thorsten, Asli Demirguc-Kunt and Ross Levine (2000): A New Database on Financial Development and Structure; World Bank Policy Research working paper \# 2147

- 一, and - (2001a): Legal Theories of Financial Development Oxford Review of Economic Policy Vol 17 \#4 pp 483-501

—, - , and - (2001b): Law Politics and Finance; World Bank Policy Research Working Paper \#2858

- , 一, and - (2003a): Law Endowments and Finance, Journal of Financial Economics Vol 70 pp137-181

- - - and -, (2003b): A New Database on Financial Development and Structure World Bank Research Dataset- update in 2003.

-, Ross Levine and Norman Loayza (2000): Finance and the Sources of Growth; Journal of Financial Economics Vol 58 pp 261-300

— George Clarke, Alberto Groff, Philip Keefer, and Patrick Walsh (2001c): New tools and new tests in comparative political economy: The Database of Political Institutions. World Bank Economic Review Updated April 3, 2003

Caprio, Gerard and Daniela Klingebiel (2003): Episodes of Systemic and Borderline Financial Crises; World Bank Research Dataset January 2003

CIA World Factbook (http://www.reference-guides.com/cia_world_factbook)

Demetriades, Panicos and Svetlana Andrianova (2004): Finance and Growth: What We Know and What We Need to Know in Charles Goodhart (ed) Money, Finance and Growth, Routledge, forthcoming

Demetriades, Panicos and K Hussein (1996): Does Financial Development cause Economic Growth? Time Series Evidence from 16 Countries Journal of Development Economics vol51 pp387-411

Demirguec-Kunt A and Detragiache, E. (1998): The Determinants of Banking Crises in Developed and Developing Countries IMF Working Paper \#106 
Demirguec-Kunt A and Detragiache, E. (1998): Financial Liberalisation and Financial Fragility Annual World Bank Conference on Development Economics 1998.

Frankel Jeffrey and David Romer (1999): Does Trade Cause Growth? American Economic Review Vol 89 no 3 pp 379-399:

Fry, Maxwell (1997): In Defence of Financial Liberalisation. Economic Journal Vol 107 pp754-770

Glick Reuven and Michael Hutchinson. (1999): Banking and Currency Crises How Common Are Twins? Pacific Basin Working Paper Series \# PB99/07 Federal Reserve Bank of San Francisco

Haggard, Stephan and Sylvia Maxfield (1996): The Political Economy of Financial Internationalisation in the Developing World; International Organization Vol 50 pp35-68

Hansen, L (1982). 'Large sample properties of generalized method of moments estimators', Econometrica, Vol. 50, 1029-1054.

Hellmann, Thomas, Kevin Murdock and Joseph Stiglitz (2000): Liberalisation. Moral Hazard in Banking and Prudential Regulation Are Capital Requirements Enough? American Economic Review Vol 90 no 1 pp 147-165

Kaminsky, Graciela and Carmen Reinhart (1999): The Twin Crises: the causes of banking and balance-of payments problems; American Economic Review vol 89 (3) pp 473-500

Kaufmann D., A. Kraay, and P. Zoido-Lobaton (1999), Governance Matters; World Bank Working Paper \#2196

La Porta, Rafael, Lopez-de-Silanes, Florencio, Shleifer, Andrei. (2002): Government Ownership of Banks; Journal of International Finance, Vol 57 n0 1 pp265-301

—, Shleifer, Andrei and Vishny, R (1997): Legal Determinants of External Finance; Journal of Finance Vol 52 no3; pp1131-1150

—, - and -, (1998): Law and Finance Journal of Political Economy vol 106 no6 pp $1113-1155$.

Levine, Ross (2003): More on Finance and Growth: More Finance, More Growth? Federal Reserve Bank of St Louis Review Vol 85 no 4 pp31-46

Li, Quan and Dale L. Smith (2003) "Liberalizing Capital Controls: Economic Pluralism or Political Institutions?" in Policymaking and Prosperity: A Multinational Anthology, edited by Stuart Nagel. New York: Lexington Books, pp.1-22. 
Lindgren, C; G Garcia and M Saal (1996): Bank Soundness and Macroeconomic Management International Monetary Fund Washington DC

Linnemann, Hans (1966): An Econometric Study of International Trade Flows; North Holland Amsterdam

Marshall, Monty Keith Jaggers, and Ted Robert Gurr: Political Regime Characteristics and Transitions, 1800-2002, Data-set and Data-set Users Manual; http://www.cidem.umd.edu/inscr/polity

McKinnon, Ronald (1973): Money and Capital in Economic Development Brookings Institution Washington DC

North Douglas (1990): Institutions, Institutional Change and Economic Performance; Cambridge University Press, Cambridge

Olson Mancur (1993): Dictatorship, Democracy and Development; American Political Science Review vol 87 pp567-76

Pagano Marco and Paolo Volpin (1999): The Political Economy of Corporate Governance CSEF Working Paper \#29 http://www.dise.unisa.it/WP/wp29.pdf

Perotti, Enrico (2001) Banking Regulation in a Context of Extreme Legal Underdevelopment; in Westin, P. (ed) (2001): The Wild East: Negotiating the Russian Financial Frontier; Reuters, Pearson Education.

Rajan, Raghuram and Luigi Zingales (2001): Financial Systems, Industrial Structure and Growth; Oxford Review of Economic Policy Vol 17 \#4 pp 467-482

- and - (2003): The Great Reversals: the Politics of Financial Development in the Twentieth Century; Journal of Financial Economics Vol 69 pp 5-50

Rousseeuw, P. J. and A. M. Leroy (1987), Robust Regression and Outlier Detection, John Wiley, New York

Shaw E.S. (1973): Financial Deepening in Economic Development; Oxford University Press New York

Staiger, D and Stock, J.H (1997). ' Instrumental variables regression with weak instruments', Econometrica 1997, 55, 557-586.

Taylor, Alan (1998): Argentina and the World Capital Market: Saving, Investment and International Capital Mobility in the $20^{\text {th }}$ Century; Journal of Development Economics Vol 57 pp 147-184

Zanella Fernando, Robert Ekelund and David Laband (2003): Monarchy, Monopoly and Mercantilism: Brazil versus the United States in the 1800s Public Choice Vol 116 pp 381-398 
Diagrams 1-3
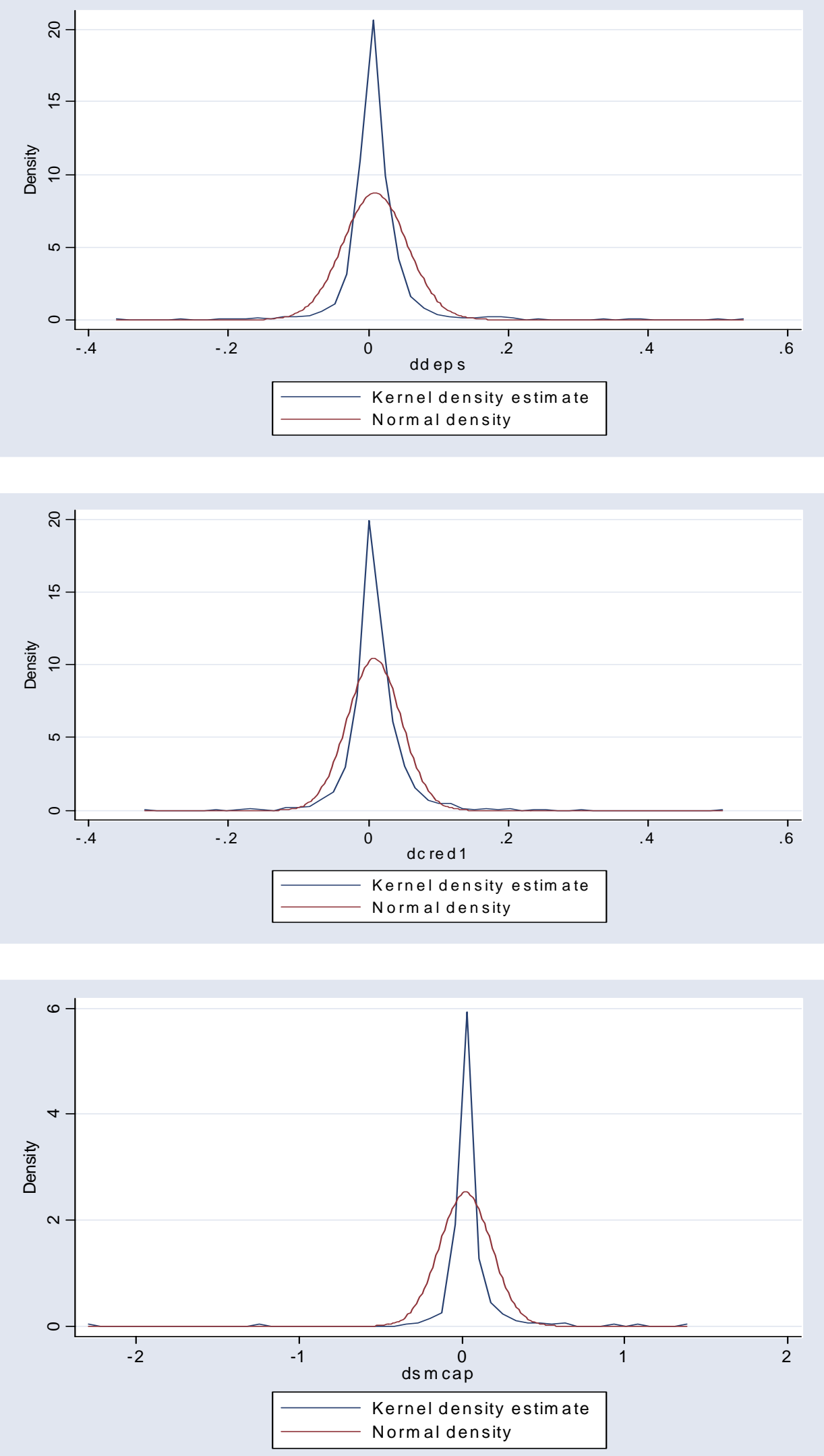
Table 1a

Financial growth and politics:

Summary statistics

\begin{tabular}{l|rrrrr}
\hline & Deposits & Credit & Stock & Polity2 & Durability \\
\hline Mean & 0.009 & 0.010 & 0.023 & 0.439 & 22.198 \\
Standard deviation & 0.038 & 0.046 & 0.158 & 7.612 & 24.029 \\
Lower quartile & -0.007 & -0.006 & -0.009 & -7 & 4 \\
Median & 0.006 & 0.006 & 0.008 & -1 & 14 \\
Upper quartile & 0.022 & 0.021 & 0.045 & 9 & 31 \\
\hline
\end{tabular}

Table $1 b$

Pair-wise correlations on speed of financial development

\begin{tabular}{|c|c|}
\hline & d.credit d.deposits d.smcap polity2 herfind. durabil. lgrowth lbank. trade \\
\hline d.credit & 1.0000 \\
\hline d.deposits & $0.4211 \quad 1.0000$ \\
\hline d. sm cap & $\begin{array}{lll}-0.0123 & 0.0665 & 1.0000\end{array}$ \\
\hline Polity2 & $\begin{array}{llll}0.0556 & 0.0676 & 0.0650 & 1.0000\end{array}$ \\
\hline Herfindahl & $-0.0584-0.0733-0.0516-0.6322 \quad 1.0000$ \\
\hline Durability & $\begin{array}{llllll}0.0868 & 0.1056 & 0.0831 & 0.2293 & -0.1363 & 1.0000 \\
\end{array}$ \\
\hline 1.growth & $\begin{array}{llllll}0.0840 & -0.0155 & -0.0487 & 0.0104 & 0.0506 & 1.0000\end{array}$ \\
\hline 1.bank crisis & $\begin{array}{llllllll}-0.0791 & -0.0401 & -0.0577 & 0.0997 & -0.0969 & -0.0781 & -0.0656 & 1.0000\end{array}$ \\
\hline trade & $\begin{array}{lllllllll}0.0495 & 0.1655 & 0.0203 & 0.0372 & -0.0855 & 0.1433 & 0.0401 & -0.1104 & 1.0000\end{array}$ \\
\hline
\end{tabular}


Table 2

\begin{tabular}{|c|c|c|c|c|c|c|}
\hline & \multicolumn{3}{|c|}{ OLS with robust standard errors } & \multicolumn{3}{|c|}{ Outlier robust regression } \\
\hline & $\Delta$ credit & $\Delta$ smtrade & $\Delta$ smcap & $\Delta$ credit & $\Delta$ dsmtrade & $\triangle$ smcap \\
\hline \multirow[t]{2}{*}{ polity2 } & 0.0003 & 0.0007 & 0.0010 & 0.0002 & 0.0001 & 0.0002 \\
\hline & $(0.0002)^{* *}$ & $(0.0004)$ & $(0.0003)^{* * *}$ & $(0.0001)^{* * *}$ & $(0.0001)$ & $(0.0002)$ \\
\hline \multirow[t]{2}{*}{ durability 2} & 0.0002 & 0.0006 & 0.0004 & 0.0001 & 0.0001 & 0.0002 \\
\hline & $(0.0000)^{* * *}$ & $(0.0002)^{* *}$ & $(0.0002)^{* *}$ & $(0.0000)^{* * *}$ & $(0.0000)^{* * *}$ & $(0.0000)^{* * *}$ \\
\hline \multirow[t]{2}{*}{ trade } & 0.0037 & -0.0169 & -0.0018 & 0.0041 & -0.0020 & -0.0154 \\
\hline & $(0.0023)$ & $(0.0068)^{* *}$ & $(0.0051)$ & $(0.0019)^{* *}$ & $(0.0015)$ & $(0.0033)^{* * *}$ \\
\hline \multirow[t]{2}{*}{ Lbankcris } & -0.0080 & -0.0153 & -0.0206 & -0.0079 & -0.0002 & -0.0108 \\
\hline & $(0.0033)^{* *}$ & $(0.0076)^{* *}$ & $(0.0092)^{* *}$ & $(0.0015)^{* * *}$ & $(0.0014)$ & $(0.0030)^{* * *}$ \\
\hline \multirow[t]{2}{*}{ Lgdpgrowth } & 0.0010 & -0.0017 & -0.0005 & 0.0009 & -0.0002 & 0.0003 \\
\hline & $(0.0003)^{* * *}$ & $(0.0009)^{*}$ & $(0.0017)$ & $(0.0001)^{* * *}$ & $(0.0001)$ & $(0.0003)$ \\
\hline \multirow[t]{2}{*}{ legor $==2$} & 0.0005 & 0.0093 & 0.0065 & 0.0001 & -0.0004 & 0.0052 \\
\hline & $(0.0020)$ & $(0.0086)$ & $(0.0075)$ & $(0.0011)$ & $(0.0011)$ & $(0.0025)^{* *}$ \\
\hline \multirow[t]{2}{*}{ legor $==5$} & 0.0290 & 0.0462 & 0.0298 & 0.0150 & 0.0644 & 0.0134 \\
\hline & $(0.0079)^{* * *}$ & $(0.0128)^{* * *}$ & $(0.0124) * *$ & $(0.0058)^{* * *}$ & $(0.0064)^{* * *}$ & $(0.0146)$ \\
\hline \multirow[t]{2}{*}{ year $==1976$} & 0.0000 & 0.0000 & 0.0000 & 0.0000 & 0.0000 & 0.0000 \\
\hline & $(0.0000)$ & $(0.0000)$ & $(0.0000)$ & $(0.0000)$ & $(0.0000)$ & $(0.0000)$ \\
\hline \multirow[t]{2}{*}{ year $==1977$} & 0.0031 & 0.0093 & -0.0018 & 0.0054 & -0.0017 & -0.0013 \\
\hline & $(0.0028)$ & $(0.0046)^{* *}$ & $(0.0095)$ & $(0.0040)$ & $(0.0051)$ & $(0.0121)$ \\
\hline \multirow[t]{2}{*}{ year $==1978$} & 0.0131 & 0.0077 & 0.0000 & 0.0098 & 0.0047 & 0.0000 \\
\hline & $(0.0038)^{* * *}$ & $(0.0112)$ & $(0.0000)$ & $(0.0039)^{* *}$ & $(0.0051)$ & $(0.0000)$ \\
\hline \multirow[t]{2}{*}{ year $==1979$} & 0.0092 & 0.0021 & 0.0170 & 0.0031 & 0.0012 & 0.0063 \\
\hline & $(0.0051)^{*}$ & $(0.0064)$ & $(0.0077)^{* *}$ & $(0.0039)$ & $(0.0051)$ & $(0.0110)$ \\
\hline \multirow[t]{2}{*}{ year $==1980$} & 0.0019 & 0.0174 & 0.0209 & 0.0028 & 0.0040 & 0.0056 \\
\hline & $(0.0035)$ & $(0.0078)^{* *}$ & $(0.0091)^{* *}$ & $(0.0039)$ & $(0.0051)$ & $(0.0109)$ \\
\hline \multirow[t]{2}{*}{ year $==1981$} & 0.0118 & 0.0113 & 0.0133 & 0.0095 & 0.0012 & 0.0051 \\
\hline & $(0.0035)^{* * *}$ & $(0.0064)^{*}$ & $(0.0072)^{*}$ & $(0.0039)^{* *}$ & $(0.0049)$ & $(0.0107)$ \\
\hline \multirow[t]{2}{*}{ year $==1982$} & 0.0159 & -0.0055 & 0.0154 & 0.0085 & -0.0015 & 0.0021 \\
\hline & $(0.0040)^{* * *}$ & $(0.0103)$ & $(0.0093)$ & $(0.0039)^{* *}$ & $(0.0049)$ & $(0.0103)$ \\
\hline \multirow[t]{2}{*}{ year $==1983$} & 0.0070 & 0.0181 & 0.0003 & 0.0066 & 0.0055 & 0.0125 \\
\hline & $(0.0034)^{* *}$ & $(0.0075)^{* *}$ & $(0.0206)$ & $(0.0039)^{*}$ & $(0.0049)$ & $(0.0103)$ \\
\hline \multirow[t]{2}{*}{ year $==1984$} & -0.0063 & -0.0058 & 0.0062 & 0.0002 & 0.0004 & 0.0129 \\
\hline & $(0.0050)$ & $(0.0095)$ & $(0.0158)$ & $(0.0038)$ & $(0.0049)$ & $(0.0101)$ \\
\hline \multirow[t]{2}{*}{ year $==1985$} & -0.0028 & 0.0288 & 0.0438 & 0.0011 & 0.0084 & 0.0189 \\
\hline & $(0.0040)$ & $(0.0146)^{*}$ & $(0.0194)^{* *}$ & $(0.0038)$ & $(0.0048)^{*}$ & $(0.0101)^{*}$ \\
\hline \multirow[t]{2}{*}{ year $==1986$} & 0.0073 & 0.0298 & 0.0609 & 0.0051 & 0.0132 & 0.0272 \\
\hline & $(0.0053)$ & $(0.0094)^{* * *}$ & $(0.0202)^{* * *}$ & $(0.0038)$ & $(0.0048)^{* * *}$ & $(0.0101)^{* * *}$ \\
\hline \multirow[t]{2}{*}{ year $==1987$} & 0.0017 & 0.0421 & 0.0523 & 0.0036 & 0.0064 & 0.0170 \\
\hline & $(0.0052)$ & $(0.0119)^{* * *}$ & $(0.0243)^{* *}$ & $(0.0038)$ & $(0.0048)$ & $(0.0100)^{*}$ \\
\hline year $==1988$ & 0.0014 & -0.0077 & 0.0330 & 0.0030 & -0.0046 & 0.0162 \\
\hline & $(0.0049)$ & $(0.0106)$ & $(0.0153)^{* *}$ & $(0.0038)$ & $(0.0048)$ & $(0.0100)$ \\
\hline year $==1989$ & 0.0072 & 0.0305 & 0.0137 & 0.0072 & 0.0071 & 0.0293 \\
\hline & $(0.0053)$ & $(0.0109)^{* * *}$ & $(0.0380)$ & $(0.0038)^{*}$ & $(0.0048)$ & $(0.0100)^{* * *}$ \\
\hline year $==1990$ & 0.0037 & -0.0200 & -0.0503 & 0.0042 & -0.0040 & -0.0010 \\
\hline & $(0.0041)$ & $(0.0125)$ & $(0.0449)$ & $(0.0038)$ & $(0.0047)$ & $(0.0100)$ \\
\hline year==1991 & 0.0022 & 0.0015 & 0.0111 & 0.0024 & 0.0043 & 0.0126 \\
\hline & $(0.0038)$ & $(0.0086)$ & $(0.0118)$ & $(0.0038)$ & $(0.0048)$ & $(0.0099)$ \\
\hline year $==1992$ & 0.0037 & 0.0155 & 0.0276 & 0.0053 & 0.0027 & 0.0113 \\
\hline & $(0.0041)$ & $(0.0106)$ & $(0.0143)^{*}$ & $(0.0038)$ & $(0.0047)$ & $(0.0099)$ \\
\hline
\end{tabular}




\begin{tabular}{|l|l|l|l|l|l|l|}
\hline year $==1993$ & 0.0027 & 0.0936 & 0.0978 & 0.0041 & 0.0141 & 0.0364 \\
\hline & $(0.0042)$ & $(0.0359)^{* *}$ & $(0.0229)^{* * *}$ & $(0.0037)$ & $(0.0046)^{* * *}$ & $(0.0097)^{* * *}$ \\
\hline year==1994 & -0.0047 & 0.0165 & 0.0663 & -0.0008 & 0.0124 & 0.0389 \\
\hline & $(0.0038)$ & $(0.0155)$ & $(0.0147)^{* * *}$ & $(0.0037)$ & $(0.0046)^{* * *}$ & $(0.0097)^{* * *}$ \\
\hline year==1995 & 0.0043 & -0.0078 & 0.0090 & 0.0054 & -0.0020 & 0.0153 \\
\hline & $(0.0041)$ & $(0.0165)$ & $(0.0117)$ & $(0.0037)$ & $(0.0046)$ & $(0.0096)$ \\
\hline year==1996 & 0.0100 & 0.0347 & 0.0414 & 0.0068 & 0.0046 & 0.0239 \\
\hline & $(0.0042)^{* *}$ & $(0.0174)^{* *}$ & $(0.0216)^{*}$ & $(0.0037)^{*}$ & $(0.0045)$ & $(0.0095)^{* *}$ \\
\hline year==1997 & 0.0142 & 0.0616 & 0.0068 & 0.0104 & 0.0088 & 0.0283 \\
\hline & $(0.0040)^{* * *}$ & $(0.0130)^{* * *}$ & $(0.0258)$ & $(0.0037)^{* * *}$ & $(0.0045)^{*}$ & $(0.0094)^{* * *}$ \\
\hline year==1998 & 0.0251 & 0.0264 & 0.0359 & 0.0186 & 0.0008 & 0.0136 \\
\hline & $(0.0045)^{* * *}$ & $(0.0240)$ & $(0.0237)$ & $(0.0038)^{* * *}$ & $(0.0045)$ & $(0.0094)$ \\
\hline year==1999 & 0.0074 & 0.0979 & 0.0701 & 0.0082 & 0.0032 & 0.0128 \\
\hline & $(0.0048)$ & $(0.0332)^{* * *}$ & $(0.0223)^{* * *}$ & $(0.0038)^{* *}$ & $(0.0045)$ & $(0.0094)$ \\
\hline year==2000 & 0.0063 & 0.0699 & 0.0206 & 0.0039 & 0.0024 & 0.0124 \\
\hline & $(0.0085)$ & $(0.0443)$ & $(0.0215)$ & $(0.0038)$ & $(0.0045)$ & $(0.0095)$ \\
\hline Constant & -0.0054 & -0.0187 & -0.0215 & -0.0044 & -0.0020 & -0.0113 \\
\hline & $(0.0028)^{*}$ & $(0.0105)^{*}$ & $(0.0137)$ & $(0.0030)$ & $(0.0042)$ & $(0.0088)$ \\
\hline Observations & 2257 & 1338 & 1252 & 2257 & 1338 & 1252 \\
\hline R-squared & 0.08 & 0.06 & 0.05 & 0.10 & 0.16 & 0.11 \\
\hline
\end{tabular}

Robust standard errors in parentheses

$*$ significant at $10 \% ; * *$ significant at $5 \% ; * * *$ significant at $1 \%$ 
Table 3

\begin{tabular}{|c|c|c|c|c|c|c|}
\hline & \multicolumn{3}{|c|}{ OLS with robust standard errors } & \multicolumn{3}{|c|}{ Outlier robust regression } \\
\hline & $\Delta$ credit & $\Delta$ smtrade & $\Delta$ smcap & $\Delta$ credit & $\Delta$ dsmtrade & $\triangle$ smcap \\
\hline \multirow[t]{2}{*}{ polity2 } & 0.0005 & 0.0002 & 0.0009 & 0.0002 & 0.0004 & 0.0001 \\
\hline & $(0.0002)^{* *}$ & $(0.0012)$ & $(0.0009)$ & $(0.0001)^{*}$ & $(0.0002)^{* *}$ & $(0.0003)$ \\
\hline \multirow[t]{2}{*}{ Civil *polit_2 } & -0.0002 & 0.0006 & 0.0001 & -0.0000 & -0.0004 & 0.0000 \\
\hline & $(0.0003)$ & $(0.0012)$ & $(0.0010)$ & $(0.0001)$ & $(0.0002)^{* *}$ & $(0.0004)$ \\
\hline \multirow[t]{2}{*}{ Socialist*polit_5 } & -0.0021 & -0.0058 & -0.0041 & 0.0187 & -0.0097 & -0.0018 \\
\hline & $(0.0012)^{*}$ & $(0.0024)^{* *}$ & $(0.0024)^{*}$ & $(0.0051)^{* * *}$ & $(0.0009)^{* * *}$ & $(0.0021)$ \\
\hline \multirow[t]{2}{*}{ durability2 } & 0.0002 & 0.0006 & 0.0004 & 0.0001 & 0.0001 & 0.0002 \\
\hline & $(0.0000)^{* * *}$ & $(0.0002)^{* *}$ & $(0.0002)^{* *}$ & $(0.0000)^{* * *}$ & $(0.0000)^{* * *}$ & $(0.0000)^{* * *}$ \\
\hline \multirow[t]{2}{*}{ trade } & 0.0041 & -0.0177 & -0.0020 & 0.0041 & -0.0015 & -0.0155 \\
\hline & $(0.0023)^{*}$ & $(0.0068)^{* *}$ & $(0.0058)$ & $(0.0019)^{* *}$ & $(0.0015)$ & $(0.0033) * * *$ \\
\hline \multirow[t]{2}{*}{ Lbankcris } & -0.0080 & -0.0153 & -0.0206 & -0.0079 & -0.0002 & -0.0108 \\
\hline & $(0.0033)^{* *}$ & $(0.0076)^{* *}$ & $(0.0092)^{* *}$ & $(0.0015)^{* * *}$ & $(0.0014)$ & $(0.0030)^{* * *}$ \\
\hline \multirow[t]{2}{*}{ Lgdpgrowth } & 0.0010 & -0.0017 & -0.0005 & 0.0009 & -0.0002 & 0.0003 \\
\hline & $(0.0003)^{* * *}$ & $(0.0009)^{*}$ & $(0.0017)$ & $(0.0001)^{* * *}$ & $(0.0001)$ & $(0.0003)$ \\
\hline \multirow[t]{2}{*}{ legor $==2$} & 0.0011 & 0.0065 & 0.0058 & 0.0001 & 0.0010 & 0.0050 \\
\hline & $(0.0019)$ & $(0.0078)$ & $(0.0061)$ & $(0.0012)$ & $(0.0014)$ & $(0.0030)^{*}$ \\
\hline \multirow[t]{2}{*}{ legor $==5$} & 0.0172 & 0.0000 & 0.0000 & 0.1507 & 0.0000 & 0.0000 \\
\hline & $(0.0038) * * *$ & $(0.0000)$ & $(0.0000)$ & $(0.0347)^{* * * *}$ & $(0.0000)$ & $(0.0000)$ \\
\hline \multirow[t]{2}{*}{ year $==1976$} & 0.0000 & 0.0000 & 0.0000 & 0.0000 & 0.0000 & 0.0000 \\
\hline & $(0.0000)$ & $(0.0000)$ & $(0.0000)$ & $(0.0000)$ & $(0.0000)$ & $(0.0000)$ \\
\hline \multirow[t]{2}{*}{ year $==1977$} & 0.0031 & 0.0093 & -0.0018 & 0.0054 & -0.0019 & -0.0012 \\
\hline & $(0.0028)$ & $(0.0045)^{* *}$ & $(0.0095)$ & $(0.0039)$ & $(0.0051)$ & $(0.0121)$ \\
\hline \multirow[t]{2}{*}{ year $==1978$} & 0.0131 & 0.0079 & 0.0000 & 0.0098 & 0.0044 & 0.0000 \\
\hline & $(0.0038)^{* * *}$ & $(0.0111)$ & $(0.0000)$ & $(0.0039)^{* *}$ & $(0.0051)$ & $(0.0000)$ \\
\hline \multirow[t]{2}{*}{ year $==1979$} & 0.0093 & 0.0024 & 0.0171 & 0.0031 & 0.0009 & 0.0064 \\
\hline & $(0.0051)^{*}$ & $(0.0061)$ & $(0.0077)^{* *}$ & $(0.0039)$ & $(0.0050)$ & $(0.0110)$ \\
\hline \multirow[t]{2}{*}{ year $==1980$} & 0.0019 & 0.0177 & 0.0210 & 0.0028 & 0.0037 & 0.0057 \\
\hline & $(0.0035)$ & $(0.0079)^{* *}$ & $(0.0090)^{* *}$ & $(0.0039)$ & $(0.0050)$ & $(0.0109)$ \\
\hline \multirow[t]{2}{*}{ year $==1981$} & 0.0118 & 0.0117 & 0.0134 & 0.0095 & 0.0009 & 0.0051 \\
\hline & $(0.0035)^{* * *}$ & $(0.0065)^{*}$ & $(0.0072)^{*}$ & $(0.0039)^{* *}$ & $(0.0049)$ & $(0.0107)$ \\
\hline \multirow[t]{2}{*}{ year $==1982$} & 0.0159 & -0.0050 & 0.0155 & 0.0084 & -0.0019 & 0.0021 \\
\hline & $(0.0040)^{* * *}$ & $(0.0099)$ & $(0.0094)$ & $(0.0039)^{* *}$ & $(0.0049)$ & $(0.0103)$ \\
\hline \multirow[t]{2}{*}{ year $==1983$} & 0.0071 & 0.0185 & 0.0005 & 0.0066 & 0.0050 & 0.0125 \\
\hline & $(0.0034)^{* *}$ & $(0.0075)^{* *}$ & $(0.0208)$ & $(0.0039)^{*}$ & $(0.0049)$ & $(0.0103)$ \\
\hline \multirow[t]{2}{*}{ year $==1984$} & -0.0063 & -0.0056 & 0.0063 & 0.0001 & 0.0001 & 0.0130 \\
\hline & $(0.0050)$ & $(0.0093)$ & $(0.0159)$ & $(0.0038)$ & $(0.0048)$ & $(0.0101)$ \\
\hline year $==1985$ & -0.0026 & 0.0288 & 0.0439 & 0.0010 & 0.0083 & 0.0189 \\
\hline & $(0.0040)$ & $(0.0145)^{*}$ & $(0.0195)^{* *}$ & $(0.0038)$ & $(0.0048)^{*}$ & $(0.0101)^{*}$ \\
\hline year $==1986$ & 0.0074 & 0.0297 & 0.0609 & 0.0051 & 0.0132 & 0.0272 \\
\hline & $(0.0053)$ & $(0.0094) * * *$ & $(0.0202)^{* * *}$ & $(0.0038)$ & $(0.0048)^{* * *}$ & $(0.0101)^{* * *}$ \\
\hline year $==1987$ & 0.0019 & 0.0420 & 0.0523 & 0.0036 & 0.0065 & 0.0170 \\
\hline & $(0.0052)$ & $(0.0119)^{* * *}$ & $(0.0243)^{* *}$ & $(0.0038)$ & $(0.0047)$ & $(0.0100)^{*}$ \\
\hline year $==1988$ & 0.0017 & -0.0077 & 0.0331 & 0.0030 & -0.0047 & 0.0162 \\
\hline & $(0.0050)$ & $(0.0105)$ & $(0.0153)^{* *}$ & $(0.0038)$ & $(0.0047)$ & $(0.0100)$ \\
\hline year $==1989$ & 0.0076 & 0.0305 & 0.0138 & 0.0077 & 0.0070 & 0.0293 \\
\hline & $(0.0054)$ & $(0.0109)^{* * *}$ & $(0.0380)$ & $(0.0038)^{* *}$ & $(0.0047)$ & $(0.0100)^{* * *}$ \\
\hline year $==1990$ & 0.0039 & -0.0201 & -0.0503 & 0.0041 & -0.0039 & -0.0009 \\
\hline & $(0.0042)$ & $(0.0125)$ & $(0.0449)$ & $(0.0038)$ & $(0.0047)$ & $(0.0100)$ \\
\hline year $==1991$ & 0.0024 & 0.0015 & 0.0111 & 0.0023 & 0.0041 & 0.0126 \\
\hline
\end{tabular}




\begin{tabular}{|l|l|l|l|l|l|l|}
\hline & $(0.0038)$ & $(0.0085)$ & $(0.0119)$ & $(0.0038)$ & $(0.0047)$ & $(0.0099)$ \\
\hline year==1992 & 0.0039 & 0.0155 & 0.0276 & 0.0053 & 0.0027 & 0.0112 \\
\hline & $(0.0042)$ & $(0.0105)$ & $(0.0143)^{*}$ & $(0.0038)$ & $(0.0046)$ & $(0.0099)$ \\
\hline year==1993 & 0.0029 & 0.0935 & 0.0978 & 0.0040 & 0.0143 & 0.0364 \\
\hline & $(0.0042)$ & $(0.0360)^{* *}$ & $(0.0229)^{* * *}$ & $(0.0037)$ & $(0.0046)^{* * *}$ & $(0.0097)^{* * *}$ \\
\hline year==1994 & -0.0044 & 0.0163 & 0.0663 & -0.0008 & 0.0125 & 0.0389 \\
\hline & $(0.0038)$ & $(0.0155)$ & $(0.0147)^{* * *}$ & $(0.0037)$ & $(0.0046)^{* * *}$ & $(0.0097)^{* * *}$ \\
\hline year==1995 & 0.0045 & -0.0079 & 0.0091 & 0.0054 & -0.0019 & 0.0153 \\
\hline & $(0.0041)$ & $(0.0165)$ & $(0.0117)$ & $(0.0037)$ & $(0.0045)$ & $(0.0096)$ \\
\hline year==1996 & 0.0102 & 0.0345 & 0.0414 & 0.0067 & 0.0050 & 0.0239 \\
\hline & $(0.0043)^{* *}$ & $(0.0174)^{*}$ & $(0.0216)^{*}$ & $(0.0037)^{*}$ & $(0.0045)$ & $(0.0095)^{* *}$ \\
\hline year==1997 & 0.0144 & 0.0615 & 0.0069 & 0.0104 & 0.0085 & 0.0283 \\
\hline & $(0.0041)^{* * *}$ & $(0.0130)^{* * *}$ & $(0.0258)$ & $(0.0037)^{* * *}$ & $(0.0045)^{*}$ & $(0.0094)^{* * *}$ \\
\hline year==1998 & 0.0253 & 0.0262 & 0.0359 & 0.0186 & 0.0006 & 0.0136 \\
\hline year==1999 & $(0.0045)^{* * *}$ & $(0.0239)$ & $(0.0238)$ & $(0.0038)^{* * *}$ & $(0.0045)$ & $(0.0094)$ \\
\hline & 0.0077 & 0.0977 & 0.0701 & 0.0082 & 0.0032 & 0.0128 \\
\hline year==2000 & $(0.0047)$ & $(0.0332)^{* * *}$ & $(0.0223)^{* * *}$ & $(0.0038)^{* *}$ & $(0.0045)$ & $(0.0094)$ \\
\hline & 0.0066 & 0.0698 & 0.0206 & 0.0038 & 0.0025 & 0.0123 \\
\hline Constant & $(0.0085)$ & $(0.0443)$ & $(0.0215)$ & $(0.0038)$ & $(0.0045)$ & $(0.0095)$ \\
\hline & -0.0060 & -0.0171 & -0.0212 & -0.0044 & -0.0026 & -0.0112 \\
\hline Observations & $(0.0028)^{* *}$ & $(0.0108)$ & $(0.0130)$ & $(0.0030)$ & $(0.0042)$ & $(0.0088)$ \\
\hline R-squared & 2257 & 1338 & 1252 & 2256 & 1338 & 1252 \\
\hline
\end{tabular}

Robust standard errors in parentheses

$*$ significant at $10 \% ; * *$ significant at $5 \% ; * * *$ significant at $1 \%$ 
Table 4

\begin{tabular}{|c|c|c|c|c|c|c|}
\hline & \multicolumn{3}{|c|}{ OLS with robust standard errors } & \multicolumn{3}{|c|}{ Outlier robust regression } \\
\hline & $\Delta$ credit & $\Delta$ smtrade & $\triangle$ smcap & $\Delta$ credit & $\Delta$ dsmtrade & $\triangle$ smcap \\
\hline \multirow[t]{2}{*}{ polity2 } & -0.0002 & -0.0015 & -0.0009 & -0.0002 & -0.0001 & -0.0004 \\
\hline & $(0.0003)$ & $(0.0007)^{* *}$ & $(0.0006)$ & $(0.0002)$ & $(0.0002)$ & $(0.0006)$ \\
\hline \multirow[t]{2}{*}{$(81-85) *$ polity2 } & 0.0001 & 0.0013 & 0.0027 & 0.0004 & 0.0003 & 0.0009 \\
\hline & $(0.0003)$ & $(0.0007)^{*}$ & $(0.0013)^{* *}$ & $(0.0002)^{* *}$ & $(0.0003)$ & $(0.0007)$ \\
\hline \multirow[t]{2}{*}{$(86-90) *$ polity2 } & 0.0009 & 0.0006 & 0.0002 & 0.0007 & 0.0001 & 0.0005 \\
\hline & $(0.0005)^{* *}$ & $(0.0005)$ & $(0.0008)$ & $(0.0002)^{* * *}$ & $(0.0003)$ & $(0.0007)$ \\
\hline \multirow[t]{2}{*}{$(91-95) *$ polity2 } & 0.0005 & 0.0018 & 0.0008 & 0.0001 & 0.0004 & -0.0000 \\
\hline & $(0.0004)$ & $(0.0007)^{* *}$ & $(0.0010)$ & $(0.0002)$ & $(0.0003)$ & $(0.0007)$ \\
\hline \multirow[t]{2}{*}{$(96-2000) *$ polity 2} & 0.0011 & 0.0058 & 0.0045 & 0.0010 & 0.0003 & 0.0015 \\
\hline & $(0.0005)^{* *}$ & $(0.0014)^{* * *}$ & $(0.0012)^{* * *}$ & $(0.0002)^{* * *}$ & $(0.0003)$ & $(0.0007)^{* *}$ \\
\hline \multirow[t]{2}{*}{ durability2 } & 0.0002 & 0.0006 & 0.0004 & 0.0001 & 0.0001 & 0.0003 \\
\hline & $(0.0000)^{* * *}$ & $(0.0002)^{* *}$ & $(0.0002)^{* *}$ & $(0.0000)^{* * *}$ & $(0.0000)^{* * *}$ & $(0.0000)^{* * *}$ \\
\hline \multirow[t]{2}{*}{ trade } & 0.0045 & -0.0156 & -0.0012 & 0.0045 & -0.0019 & -0.0147 \\
\hline & $(0.0024) *$ & $(0.0067)^{* *}$ & $(0.0052)$ & $(0.0019)^{* *}$ & $(0.0015)$ & $(0.0033)^{* * *}$ \\
\hline \multirow[t]{2}{*}{ Lbankcris } & -0.0078 & -0.0151 & -0.0198 & -0.0079 & -0.0001 & -0.0105 \\
\hline & $(0.0033)^{* *}$ & $(0.0076) *$ & $(0.0089)^{* *}$ & $(0.0015)^{* * *}$ & $(0.0014)$ & $(0.0030)^{* * *}$ \\
\hline \multirow[t]{2}{*}{ Lgdpgrowth } & 0.0010 & -0.0020 & -0.0007 & 0.0009 & -0.0002 & 0.0002 \\
\hline & $(0.0003)^{* * *}$ & $(0.0009)^{* *}$ & $(0.0017)$ & $(0.0001)^{* * *}$ & $(0.0001)$ & $(0.0003)$ \\
\hline \multirow[t]{2}{*}{ legor $==2$} & -0.0001 & 0.0067 & 0.0056 & -0.0001 & -0.0006 & 0.0048 \\
\hline & $(0.0021)$ & $(0.0084)$ & $(0.0074)$ & $(0.0011)$ & $(0.0011)$ & $(0.0025)^{*}$ \\
\hline \multirow[t]{2}{*}{ legor $==5$} & 0.0313 & 0.0716 & 0.0470 & 0.0121 & 0.0658 & 0.0175 \\
\hline & $(0.0069)^{* * *}$ & $(0.0108)^{* * *}$ & $(0.0114)^{* * *}$ & $(0.0058)^{* *}$ & $(0.0065)^{* * *}$ & $(0.0150)$ \\
\hline \multirow[t]{2}{*}{ year $==1976$} & 0.0000 & 0.0000 & 0.0000 & 0.0000 & 0.0000 & 0.0000 \\
\hline & $(0.0000)$ & $(0.0000)$ & $(0.0000)$ & $(0.0000)$ & $(0.0000)$ & $(0.0000)$ \\
\hline \multirow[t]{2}{*}{ year $==1977$} & 0.0032 & 0.0044 & -0.0013 & 0.0053 & -0.0020 & -0.0009 \\
\hline & $(0.0028)$ & $(0.0047)$ & $(0.0096)$ & $(0.0039)$ & $(0.0051)$ & $(0.0123)$ \\
\hline \multirow[t]{2}{*}{ year $==1978$} & 0.0134 & 0.0034 & 0.0000 & 0.0097 & 0.0041 & 0.0000 \\
\hline & $(0.0037)^{* * *}$ & $(0.0117)$ & $(0.0000)$ & $(0.0039)^{* *}$ & $(0.0050)$ & $(0.0000)$ \\
\hline \multirow[t]{2}{*}{ year $==1979$} & 0.0098 & -0.0023 & 0.0148 & 0.0033 & 0.0009 & 0.0058 \\
\hline & $(0.0050)^{*}$ & $(0.0067)$ & $(0.0075)^{*}$ & $(0.0039)$ & $(0.0050)$ & $(0.0112)$ \\
\hline \multirow[t]{2}{*}{ year $==1980$} & 0.0025 & 0.0135 & 0.0164 & 0.0034 & 0.0035 & 0.0045 \\
\hline & $(0.0035)$ & $(0.0082)$ & $(0.0088)^{*}$ & $(0.0039)$ & $(0.0050)$ & $(0.0111)$ \\
\hline \multirow[t]{2}{*}{ year $==1981$} & 0.0120 & 0.0007 & -0.0024 & 0.0092 & -0.0006 & -0.0000 \\
\hline & $(0.0036)^{* * *}$ & $(0.0089)$ & $(0.0089)$ & $(0.0039)^{* *}$ & $(0.0051)$ & $(0.0117)$ \\
\hline \multirow[t]{2}{*}{ year $==1982$} & 0.0160 & -0.0166 & -0.0003 & 0.0080 & -0.0033 & -0.0030 \\
\hline & $(0.0040)^{* * *}$ & $(0.0128)$ & $(0.0097)$ & $(0.0039)^{* *}$ & $(0.0051)$ & $(0.0112)$ \\
\hline year $==1983$ & 0.0072 & 0.0066 & -0.0163 & 0.0061 & 0.0034 & 0.0070 \\
\hline & $(0.0034)^{* *}$ & $(0.0095)$ & $(0.0244)$ & $(0.0038)$ & $(0.0051)$ & $(0.0113)$ \\
\hline year $==1984$ & -0.0063 & -0.0173 & -0.0099 & -0.0002 & -0.0015 & 0.0076 \\
\hline & $(0.0050)$ & $(0.0116)$ & $(0.0185)$ & $(0.0038)$ & $(0.0051)$ & $(0.0111)$ \\
\hline year $==1985$ & -0.0026 & 0.0182 & 0.0275 & 0.0008 & 0.0065 & 0.0137 \\
\hline & $(0.0039)$ & $(0.0124)$ & $(0.0163)^{*}$ & $(0.0038)$ & $(0.0051)$ & $(0.0111)$ \\
\hline year $==1986$ & 0.0062 & 0.0221 & 0.0565 & 0.0046 & 0.0121 & 0.0239 \\
\hline & $(0.0051)$ & $(0.0099)^{* *}$ & $(0.0225)^{* *}$ & $(0.0038)$ & $(0.0050)^{* *}$ & $(0.0111)^{* *}$ \\
\hline year $==1987$ & 0.0008 & 0.0349 & 0.0483 & 0.0031 & 0.0050 & 0.0138 \\
\hline & $(0.0050)$ & $(0.0125)^{* * *}$ & $(0.0265)^{*}$ & $(0.0038)$ & $(0.0050)$ & $(0.0111)$ \\
\hline year $==1988$ & 0.0003 & -0.0140 & 0.0286 & 0.0024 & -0.0054 & 0.0126 \\
\hline & $(0.0046)$ & $(0.0117)$ & $(0.0171)^{*}$ & $(0.0038)$ & $(0.0050)$ & $(0.0110)$ \\
\hline year $==1989$ & 0.0059 & 0.0247 & 0.0100 & 0.0066 & 0.0062 & 0.0263 \\
\hline & $(0.0050)$ & $(0.0127)^{*}$ & $(0.0363)$ & $(0.0038)^{*}$ & $(0.0050)$ & $(0.0110)^{* *}$ \\
\hline
\end{tabular}




\begin{tabular}{|l|l|l|l|l|l|l|}
\hline year $==1990$ & 0.0022 & -0.0259 & -0.0540 & 0.0033 & -0.0047 & -0.0049 \\
\hline & $(0.0040)$ & $(0.0136)^{*}$ & $(0.0431)$ & $(0.0038)$ & $(0.0050)$ & $(0.0110)$ \\
\hline year==1991 & 0.0018 & -0.0112 & 0.0037 & 0.0028 & 0.0019 & 0.0111 \\
\hline & $(0.0039)$ & $(0.0101)$ & $(0.0116)$ & $(0.0038)$ & $(0.0050)$ & $(0.0110)$ \\
\hline year==1992 & 0.0033 & 0.0021 & 0.0201 & 0.0059 & 0.0004 & 0.0099 \\
\hline & $(0.0042)$ & $(0.0123)$ & $(0.0158)$ & $(0.0038)$ & $(0.0049)$ & $(0.0110)$ \\
\hline year==1993 & 0.0023 & 0.0803 & 0.0900 & 0.0048 & 0.0118 & 0.0354 \\
\hline & $(0.0042)$ & $(0.0360)^{* *}$ & $(0.0237)^{* * *}$ & $(0.0038)$ & $(0.0049)^{* *}$ & $(0.0108)^{* * *}$ \\
\hline year==1994 & -0.0050 & 0.0031 & 0.0584 & -0.0001 & 0.0103 & 0.0388 \\
\hline & $(0.0039)$ & $(0.0156)$ & $(0.0165)^{* * *}$ & $(0.0038)$ & $(0.0049)^{* *}$ & $(0.0108)^{* * *}$ \\
\hline year==1995 & 0.0039 & -0.0207 & 0.0013 & 0.0065 & -0.0043 & 0.0149 \\
\hline & $(0.0043)$ & $(0.0167)$ & $(0.0116)$ & $(0.0038)^{*}$ & $(0.0048)$ & $(0.0107)$ \\
\hline year==1996 & 0.0069 & -0.0004 & 0.0145 & 0.0036 & 0.0028 & 0.0152 \\
\hline year==1997 & $(0.0043)$ & $(0.0182)$ & $(0.0207)$ & $(0.0038)$ & $(0.0048)$ & $(0.0106)$ \\
\hline & 0.0111 & 0.0261 & -0.0206 & 0.0076 & 0.0068 & 0.0193 \\
\hline year==1998 & $(0.0043)^{* *}$ & $(0.0122)^{* *}$ & $(0.0250)$ & $(0.0038)^{* *}$ & $(0.0048)$ & $(0.0106)^{*}$ \\
\hline & 0.0220 & -0.0098 & 0.0078 & 0.0155 & -0.0007 & 0.0043 \\
\hline year==1999 & $(0.0047)^{* * *}$ & $(0.0227)$ & $(0.0221)$ & $(0.0038)^{* * *}$ & $(0.0048)$ & $(0.0106)$ \\
\hline & 0.0043 & 0.0610 & 0.0416 & 0.0051 & 0.0014 & 0.0052 \\
\hline year==2000 & $(0.0045)$ & $(0.0325)^{*}$ & $(0.0179)^{* *}$ & $(0.0038)$ & $(0.0048)$ & $(0.0106)$ \\
\hline & 0.0030 & 0.0329 & -0.0082 & 0.0013 & 0.0006 & 0.0034 \\
\hline Constant & $(0.0076)$ & $(0.0407)$ & $(0.0201)$ & $(0.0039)$ & $(0.0048)$ & $(0.0106)$ \\
\hline & -0.0048 & -0.0018 & -0.0079 & -0.0039 & -0.0003 & -0.0073 \\
\hline Observations & $(0.0027)^{*}$ & $(0.0087)$ & $(0.0129)$ & $(0.0030)$ & $(0.0044)$ & $(0.0097)$ \\
\hline R-squared & 2257 & 1338 & 1252 & 2257 & 1338 & 1252 \\
\hline & 0.09 & 0.07 & 0.05 & 0.11 & 0.16 & 0.12 \\
\hline
\end{tabular}

Robust standard errors in parentheses

significant at $10 \%$; * significant at $5 \%$; *** significant at $1 \%$ 
Table 5

\begin{tabular}{|c|c|c|c|c|c|c|}
\hline & \multicolumn{3}{|c|}{ OLS with robust standard errors } & \multicolumn{3}{|c|}{ Outlier robust regression } \\
\hline & $\Delta$ credit & $\Delta$ smtrade & $\Delta$ smcap & $\Delta$ credit & $\Delta$ dsmtrade & $\Delta$ smcap \\
\hline \multirow[t]{2}{*}{ Lagged level } & 0.0108 & 0.0011 & -0.0587 & 0.0202 & 0.0497 & 0.0467 \\
\hline & $(0.0032)^{* * *}$ & $(0.0810)$ & $(0.0388)$ & $(0.0022)^{* * *}$ & $(0.0021)^{* * *}$ & $(0.0032)^{* * *}$ \\
\hline \multirow[t]{2}{*}{ polity2 } & 0.0002 & 0.0006 & 0.0011 & -0.0000 & 0.0001 & 0.0002 \\
\hline & $(0.0001)$ & $(0.0005)$ & $(0.0004)^{* *}$ & $(0.0001)$ & $(0.0001)$ & $(0.0002)$ \\
\hline \multirow[t]{2}{*}{ durability2 } & 0.0001 & 0.0006 & 0.0006 & 0.0000 & 0.0000 & 0.0001 \\
\hline & $(0.0000)^{* *}$ & $(0.0002)^{* *}$ & $(0.0002)^{* * *}$ & $(0.0000)$ & $(0.0000)^{* *}$ & $(0.0000)^{* *}$ \\
\hline \multirow[t]{2}{*}{ trade } & 0.0014 & -0.0169 & 0.0293 & 0.0002 & -0.0008 & -0.0242 \\
\hline & $(0.0021)$ & $(0.0066)^{* *}$ & $(0.0231)$ & $(0.0019)$ & $(0.0014)$ & $(0.0037)^{* * *}$ \\
\hline \multirow[t]{2}{*}{ Lbankcris } & -0.0077 & -0.0153 & -0.0235 & -0.0074 & 0.0001 & -0.0104 \\
\hline & $(0.0033)^{* *}$ & $(0.0089)^{*}$ & $(0.0095)^{* *}$ & $(0.0014)^{* * *}$ & $(0.0013)$ & $(0.0030)^{* * *}$ \\
\hline \multirow[t]{2}{*}{ Lgdpgrowth } & 0.0010 & -0.0017 & 0.0002 & 0.0009 & -0.0002 & 0.0002 \\
\hline & $(0.0003)^{* * *}$ & $(0.0011)$ & $(0.0015)$ & $(0.0001)^{* * *}$ & $(0.0001)$ & $(0.0003)$ \\
\hline \multirow[t]{2}{*}{ Ilegor_2 } & -0.0002 & 0.0093 & -0.0014 & -0.0013 & -0.0009 & 0.0079 \\
\hline & $(0.0018)$ & $(0.0084)$ & $(0.0124)$ & $(0.0011)$ & $(0.0011)$ & $(0.0025)^{* * *}$ \\
\hline \multirow[t]{2}{*}{ Ilegor_5 } & 0.0243 & 0.0463 & 0.0080 & 0.0102 & 0.0599 & 0.0223 \\
\hline & $(0.0100)^{* *}$ & $(0.0121)^{* * *}$ & $(0.0141)$ & $(0.0057)^{*}$ & $(0.0060)^{* * *}$ & $(0.0145)$ \\
\hline \multirow[t]{2}{*}{ IIyear_1976 } & 0.0000 & 0.0000 & 0.0000 & 0.0000 & 0.0000 & 0.0000 \\
\hline & $(0.0000)$ & $(0.0000)$ & $(0.0000)$ & $(0.0000)$ & $(0.0000)$ & $(0.0000)$ \\
\hline \multirow[t]{2}{*}{ _Iyear_1977 } & 0.0030 & 0.0093 & -0.0030 & 0.0054 & -0.0015 & -0.0005 \\
\hline & $(0.0028)$ & $(0.0045)^{* *}$ & $(0.0090)$ & $(0.0038)$ & $(0.0048)$ & $(0.0121)$ \\
\hline \multirow[t]{2}{*}{ Iyear_1978 } & 0.0130 & 0.0078 & 0.0000 & 0.0101 & 0.0045 & 0.0000 \\
\hline & $(0.0038)^{* * *}$ & $(0.0111)$ & $(0.0000)$ & $(0.0038)^{* * *}$ & $(0.0048)$ & $(0.0000)$ \\
\hline \multirow[t]{2}{*}{ Iyear_1979 } & 0.0090 & 0.0021 & 0.0172 & 0.0031 & 0.0006 & 0.0067 \\
\hline & $(0.0051)^{*}$ & $(0.0064)$ & $(0.0075)^{* *}$ & $(0.0038)$ & $(0.0047)$ & $(0.0109)$ \\
\hline \multirow[t]{2}{*}{ Iyear_1980 } & 0.0015 & 0.0174 & 0.0216 & 0.0029 & 0.0031 & 0.0063 \\
\hline & $(0.0035)$ & $(0.0074)^{* *}$ & $(0.0090)^{* *}$ & $(0.0038)$ & $(0.0048)$ & $(0.0108)$ \\
\hline \multirow[t]{2}{*}{ Iyear_1981 } & 0.0114 & 0.0113 & 0.0150 & 0.0090 & 0.0002 & 0.0045 \\
\hline & $(0.0035)^{* * *}$ & $(0.0064)^{*}$ & $(0.0072)^{* *}$ & $(0.0038)^{* *}$ & $(0.0046)$ & $(0.0107)$ \\
\hline \multirow[t]{2}{*}{ Iyear_1982 } & 0.0153 & -0.0055 & 0.0188 & 0.0076 & -0.0014 & 0.0008 \\
\hline & $(0.0040)^{* * *}$ & $(0.0103)$ & $(0.0102)^{*}$ & $(0.0038)^{* *}$ & $(0.0046)$ & $(0.0102)$ \\
\hline \multirow[t]{2}{*}{ Iyear_1983 } & 0.0063 & 0.0181 & 0.0051 & 0.0058 & 0.0051 & 0.0136 \\
\hline & $(0.0034)^{*}$ & $(0.0076)^{* *}$ & $(0.0183)$ & $(0.0038)$ & $(0.0046)$ & $(0.0102)$ \\
\hline \multirow[t]{2}{*}{ Iyear_1984 } & -0.0070 & -0.0059 & 0.0094 & -0.0008 & 0.0010 & 0.0136 \\
\hline & $(0.0051)$ & $(0.0103)$ & $(0.0152)$ & $(0.0037)$ & $(0.0046)$ & $(0.0101)$ \\
\hline \multirow[t]{2}{*}{ Iyear_1985 } & -0.0033 & 0.0288 & 0.0448 & 0.0010 & 0.0077 & 0.0207 \\
\hline & $(0.0040)$ & $(0.0144)^{* *}$ & $(0.0196)^{* *}$ & $(0.0037)$ & $(0.0045)^{*}$ & $(0.0101)^{* *}$ \\
\hline \multirow[t]{2}{*}{ Iyear_1986 } & 0.0068 & 0.0298 & 0.0641 & 0.0046 & 0.0125 & 0.0277 \\
\hline & $(0.0053)$ & $(0.0094)^{* * *}$ & $(0.0224)^{* * *}$ & $(0.0037)$ & $(0.0045)^{* * *}$ & $(0.0100)^{* * *}$ \\
\hline Iyear_ 1987 & 0.0011 & 0.0421 & 0.0577 & 0.0039 & 0.0053 & 0.0180 \\
\hline & $(0.0053)$ & $(0.0121)^{* * *}$ & $(0.0286)^{* *}$ & $(0.0037)$ & $(0.0045)$ & $(0.0100)^{*}$ \\
\hline Iyear_1988 & 0.0008 & -0.0077 & 0.0410 & 0.0033 & -0.0043 & 0.0143 \\
\hline & $(0.0048)$ & $(0.0119)$ & $(0.0216)^{*}$ & $(0.0037)$ & $(0.0045)$ & $(0.0099)$ \\
\hline Iyear_1989 & 0.0065 & 0.0305 & 0.0226 & 0.0063 & 0.0065 & 0.0315 \\
\hline & $(0.0053)$ & $(0.0116)^{* *}$ & $(0.0310)$ & $(0.0037)^{*}$ & $(0.0045)$ & $(0.0099)^{* * *}$ \\
\hline Iyear_1990 & 0.0029 & -0.0201 & -0.0413 & 0.0035 & -0.0040 & -0.0007 \\
\hline & $(0.0041)$ & $(0.0147)$ & $(0.0396)$ & $(0.0037)$ & $(0.0045)$ & $(0.0099)$ \\
\hline Iyear_1991 & 0.0015 & 0.0015 & 0.0163 & 0.0011 & 0.0031 & 0.0092 \\
\hline & $(0.0038)$ & $(0.0090)$ & $(0.0117)$ & $(0.0037)$ & $(0.0045)$ & $(0.0099)$ \\
\hline
\end{tabular}




\begin{tabular}{|l|l|l|l|l|l|l|}
\hline Iyear_1992 & 0.0030 & 0.0155 & 0.0335 & 0.0040 & 0.0018 & 0.0092 \\
\hline & $(0.0042)$ & $(0.0114)$ & $(0.0144)^{* *}$ & $(0.0037)$ & $(0.0044)$ & $(0.0099)$ \\
\hline Iyear_1993 & 0.0021 & 0.0936 & 0.1032 & 0.0038 & 0.0122 & 0.0368 \\
\hline & $(0.0042)$ & $(0.0372)^{* *}$ & $(0.0239)^{* * *}$ & $(0.0036)$ & $(0.0043)^{* * *}$ & $(0.0097)^{* * *}$ \\
\hline Iyear_1994 & -0.0053 & 0.0164 & 0.0774 & -0.0015 & 0.0113 & 0.0353 \\
\hline & $(0.0038)$ & $(0.0155)$ & $(0.0182)^{* * *}$ & $(0.0036)$ & $(0.0043)^{* * *}$ & $(0.0097)^{* * *}$ \\
\hline Iyear_1995 & 0.0036 & -0.0079 & 0.0221 & 0.0047 & -0.0045 & 0.0091 \\
\hline & $(0.0041)$ & $(0.0171)$ & $(0.0136)$ & $(0.0036)$ & $(0.0043)$ & $(0.0096)$ \\
\hline Iyear_1996 & 0.0093 & 0.0346 & 0.0530 & 0.0063 & 0.0047 & 0.0233 \\
\hline & $(0.0042)^{* *}$ & $(0.0198)^{*}$ & $(0.0255)^{* *}$ & $(0.0036)^{*}$ & $(0.0043)$ & $(0.0095)^{* *}$ \\
\hline Iyear_1997 & 0.0134 & 0.0615 & 0.0193 & 0.0100 & 0.0062 & 0.0278 \\
\hline & $(0.0039)^{* * *}$ & $(0.0133)^{* * *}$ & $(0.0227)$ & $(0.0036)^{* * *}$ & $(0.0043)$ & $(0.0094)^{* * *}$ \\
\hline Iyear_1998 & 0.0243 & 0.0262 & 0.0481 & 0.0191 & 0.0006 & 0.0117 \\
\hline & $(0.0044)^{* * *}$ & $(0.0254)$ & $(0.0268)^{*}$ & $(0.0037)^{* * *}$ & $(0.0043)$ & $(0.0094)$ \\
\hline Iyear_1999 & 0.0064 & 0.0976 & 0.0841 & 0.0079 & 0.0010 & 0.0124 \\
\hline & $(0.0048)$ & $(0.0409)^{* *}$ & $(0.0229)^{* * *}$ & $(0.0037)^{* *}$ & $(0.0042)$ & $(0.0094)$ \\
\hline Iyear_2000 & 0.0051 & 0.0696 & 0.0389 & 0.0044 & 0.0012 & 0.0085 \\
\hline & $(0.0086)$ & $(0.0338)^{* *}$ & $(0.0180)^{* *}$ & $(0.0037)$ & $(0.0043)$ & $(0.0095)$ \\
\hline Constant & -0.0062 & -0.0187 & -0.0228 & -0.0056 & -0.0009 & -0.0136 \\
\hline & $(0.0028)^{* *}$ & $(0.0095)^{*}$ & $(0.0160)$ & $(0.0029)^{*}$ & $(0.0039)$ & $(0.0087)$ \\
\hline Observations & 2257 & 1338 & 1252 & 2257 & 1338 & 1252 \\
\hline R-squared & 0.09 & 0.06 & 0.06 & 0.13 & 0.43 & 0.26 \\
\hline Robust stan & & & & & \\
\hline
\end{tabular}

Robust standard errors in parentheses

* significant at $10 \% ; * \star$ significant at $5 \%$; ** significant at $1 \%$ 
Table 6

\begin{tabular}{|c|c|c|c|c|c|c|}
\hline & \multicolumn{3}{|c|}{ OLS with robust standard errors } & \multicolumn{3}{|c|}{ Outlier robust regression } \\
\hline & $\Delta$ credit & $\Delta$ smtrade & $\triangle$ smcap & $\Delta$ credit & $\Delta$ dsmtrade & $\triangle$ smcap \\
\hline \multirow[t]{2}{*}{ Lagged Level } & 0.0108 & 0.0007 & -0.0587 & 0.0202 & 0.0501 & 0.0472 \\
\hline & $(0.0031)^{* * *}$ & $(0.0813)$ & $(0.0388)$ & $(0.0022)^{* * *}$ & $(0.0021)^{* * *}$ & $(0.0031)^{* * *}$ \\
\hline \multirow[t]{2}{*}{ polity2 } & 0.0003 & 0.0002 & 0.0011 & 0.0000 & 0.0004 & -0.0000 \\
\hline & $(0.0002)^{* *}$ & $(0.0012)$ & $(0.0010)$ & $(0.0001)$ & $(0.0001)^{* *}$ & $(0.0003)$ \\
\hline \multirow[t]{2}{*}{ Civil *polit_2 } & -0.0002 & 0.0006 & 0.0000 & -0.0000 & -0.0004 & 0.0003 \\
\hline & $(0.0003)$ & $(0.0013)$ & $(0.0011)$ & $(0.0001)$ & $(0.0002)^{* *}$ & $(0.0004)$ \\
\hline \multirow[t]{2}{*}{ Socialist*polit_5 } & -0.0019 & -0.0058 & -0.0011 & 0.0186 & -0.0090 & -0.0028 \\
\hline & $(0.0014)$ & $(0.0024)^{* *}$ & $(0.0024)$ & $(0.0050)^{* * *}$ & $(0.0009)^{* * *}$ & $(0.0021)$ \\
\hline \multirow[t]{2}{*}{ durability2 } & 0.0001 & 0.0006 & 0.0006 & 0.0000 & 0.0000 & 0.0001 \\
\hline & $(0.0000)^{* *}$ & $(0.0002)^{* *}$ & $(0.0002)^{* * *}$ & $(0.0000)$ & $(0.0000)$ & $(0.0000)^{* *}$ \\
\hline \multirow[t]{2}{*}{ trade } & 0.0018 & -0.0177 & 0.0293 & 0.0002 & -0.0003 & -0.0246 \\
\hline & $(0.0021)$ & $(0.0068)^{* *}$ & $(0.0236)$ & $(0.0019)$ & $(0.0014)$ & $(0.0037)^{* * *}$ \\
\hline \multirow[t]{2}{*}{ Lbankcris } & -0.0077 & -0.0153 & -0.0235 & -0.0075 & 0.0001 & -0.0104 \\
\hline & $(0.0033)^{* *}$ & $(0.0089)^{*}$ & $(0.0095)^{* *}$ & $(0.0014)^{* * *}$ & $(0.0013)$ & $(0.0030)^{* * *}$ \\
\hline \multirow[t]{2}{*}{ Lgdpgrowth } & 0.0010 & -0.0017 & 0.0002 & 0.0009 & -0.0002 & 0.0002 \\
\hline & $(0.0003)^{* * *}$ & $(0.0010)$ & $(0.0015)$ & $(0.0001)^{* * *}$ & $(0.0001)^{*}$ & $(0.0003)$ \\
\hline \multirow[t]{2}{*}{ Ilegor_2 } & 0.0004 & 0.0066 & -0.0016 & -0.0013 & 0.0005 & 0.0068 \\
\hline & $(0.0018)$ & $(0.0083)$ & $(0.0102)$ & $(0.0012)$ & $(0.0013)$ & $(0.0030)^{* *}$ \\
\hline \multirow[t]{2}{*}{ Ilegor_5 } & 0.0142 & 0.0000 & 0.0000 & 0.1449 & 0.0000 & 0.0000 \\
\hline & $(0.0042)^{* * *}$ & $(0.0000)$ & $(0.0000)$ & $(0.0337)^{* * *}$ & $(0.0000)$ & $(0.0000)$ \\
\hline \multirow[t]{2}{*}{ _Iyear_1976 } & 0.0000 & 0.0000 & 0.0000 & 0.0000 & 0.0000 & 0.0000 \\
\hline & $(0.0000)$ & $(0.0000)$ & $(0.0000)$ & $(0.0000)$ & $(0.0000)$ & $(0.0000)$ \\
\hline \multirow[t]{2}{*}{ _Iyear_1977 } & 0.0030 & 0.0093 & -0.0029 & 0.0054 & -0.0016 & -0.0002 \\
\hline & $(0.0028)$ & $(0.0044)^{* *}$ & $(0.0090)$ & $(0.0038)$ & $(0.0048)$ & $(0.0121)$ \\
\hline \multirow[t]{2}{*}{ Iyear_1978 } & 0.0130 & 0.0079 & 0.0000 & 0.0101 & 0.0042 & 0.0000 \\
\hline & $(0.0038)^{* * *}$ & $(0.0111)$ & $(0.0000)$ & $(0.0038)^{* * *}$ & $(0.0048)$ & $(0.0000)$ \\
\hline \multirow[t]{2}{*}{ _Iyear_1979 } & 0.0091 & 0.0024 & 0.0172 & 0.0031 & 0.0003 & 0.0068 \\
\hline & $(0.0051)^{*}$ & $(0.0061)$ & $(0.0076)^{* *}$ & $(0.0038)$ & $(0.0047)$ & $(0.0109)$ \\
\hline \multirow[t]{2}{*}{ Iyear_1980 } & 0.0016 & 0.0177 & 0.0217 & 0.0030 & 0.0029 & 0.0063 \\
\hline & $(0.0035)$ & $(0.0075)^{* *}$ & $(0.0090)^{* *}$ & $(0.0038)$ & $(0.0047)$ & $(0.0108)$ \\
\hline \multirow[t]{2}{*}{ Iyear_1981 } & 0.0114 & 0.0117 & 0.0151 & 0.0090 & -0.0001 & 0.0047 \\
\hline & $(0.0035)^{* * *}$ & $(0.0066)^{*}$ & $(0.0072)^{* *}$ & $(0.0038)^{* *}$ & $(0.0046)$ & $(0.0106)$ \\
\hline \multirow[t]{2}{*}{ _Iyear_1982 } & 0.0153 & -0.0050 & 0.0188 & 0.0076 & -0.0018 & 0.0010 \\
\hline & $(0.0040)^{* * *}$ & $(0.0099)$ & $(0.0104)^{*}$ & $(0.0038)^{* *}$ & $(0.0046)$ & $(0.0102)$ \\
\hline \multirow[t]{2}{*}{ Iyear_1983 } & 0.0064 & 0.0185 & 0.0051 & 0.0058 & 0.0046 & 0.0139 \\
\hline & $(0.0035)^{*}$ & $(0.0077)^{* *}$ & $(0.0184)$ & $(0.0038)$ & $(0.0046)$ & $(0.0102)$ \\
\hline Iyear_1984 & -0.0070 & -0.0056 & 0.0094 & -0.0009 & 0.0009 & 0.0136 \\
\hline & $(0.0051)$ & $(0.0102)$ & $(0.0153)$ & $(0.0037)$ & $(0.0045)$ & $(0.0101)$ \\
\hline Iyear_1985 & -0.0031 & 0.0288 & 0.0448 & 0.0010 & 0.0076 & 0.0208 \\
\hline & $(0.0040)$ & $(0.0144)^{* *}$ & $(0.0196)^{* *}$ & $(0.0037)$ & $(0.0045)^{*}$ & $(0.0100)^{* *}$ \\
\hline Iyear_1986 & 0.0070 & 0.0298 & 0.0641 & 0.0045 & 0.0126 & 0.0277 \\
\hline & $(0.0053)$ & $(0.0094)^{* * *}$ & $(0.0224)^{* * *}$ & $(0.0037)$ & $(0.0045)^{* * *}$ & $(0.0100)^{* * *}$ \\
\hline Iyear_1987 & 0.0014 & 0.0420 & 0.0577 & 0.0039 & 0.0054 & 0.0180 \\
\hline & $(0.0053)$ & $(0.0120)^{* * *}$ & $(0.0286)^{* *}$ & $(0.0037)$ & $(0.0045)$ & $(0.0100)^{*}$ \\
\hline Iyear_1988 & 0.0011 & -0.0077 & 0.0410 & 0.0034 & -0.0044 & 0.0143 \\
\hline & $(0.0050)$ & $(0.0118)$ & $(0.0216)^{*}$ & $(0.0037)$ & $(0.0045)$ & $(0.0099)$ \\
\hline Iyear_1989 & 0.0069 & 0.0305 & 0.0226 & 0.0068 & 0.0064 & 0.0314 \\
\hline & $(0.0054)$ & $(0.0116)^{* *}$ & $(0.0310)$ & $(0.0037)^{*}$ & $(0.0045)$ & $(0.0099)^{* * *}$ \\
\hline Iyear 1990 & 0.0032 & -0.0201 & -0.0413 & 0.0035 & -0.0040 & -0.0005 \\
\hline
\end{tabular}




\begin{tabular}{|l|l|l|l|l|l|l|}
\hline & $(0.0042)$ & $(0.0147)$ & $(0.0396)$ & $(0.0037)$ & $(0.0045)$ & $(0.0099)$ \\
\hline Iyear_1991 & 0.0017 & 0.0015 & 0.0163 & 0.0010 & 0.0030 & 0.0091 \\
\hline & $(0.0038)$ & $(0.0089)$ & $(0.0117)$ & $(0.0037)$ & $(0.0045)$ & $(0.0099)$ \\
\hline Iyear_1992 & 0.0032 & 0.0155 & 0.0335 & 0.0041 & 0.0018 & 0.0091 \\
\hline & $(0.0042)$ & $(0.0114)$ & $(0.0144)^{* *}$ & $(0.0037)$ & $(0.0044)$ & $(0.0099)$ \\
\hline Iyear_1993 & 0.0023 & 0.0934 & 0.1032 & 0.0038 & 0.0124 & 0.0367 \\
\hline & $(0.0042)$ & $(0.0372)^{* *}$ & $(0.0239)^{* * *}$ & $(0.0036)$ & $(0.0043)^{* * *}$ & $(0.0097)^{* * *}$ \\
\hline Iyear_1994 & -0.0051 & 0.0163 & 0.0774 & -0.0015 & 0.0114 & 0.0354 \\
\hline & $(0.0038)$ & $(0.0154)$ & $(0.0182)^{* * *}$ & $(0.0036)$ & $(0.0043)^{* * *}$ & $(0.0096)^{* * *}$ \\
\hline Iyear_1995 & 0.0039 & -0.0080 & 0.0221 & 0.0048 & -0.0044 & 0.0090 \\
\hline & $(0.0041)$ & $(0.0171)$ & $(0.0136)$ & $(0.0036)$ & $(0.0043)$ & $(0.0096)$ \\
\hline Iyear_1996 & 0.0095 & 0.0345 & 0.0530 & 0.0062 & 0.0052 & 0.0233 \\
\hline & $(0.0042)^{* *}$ & $(0.0198)^{*}$ & $(0.0256)^{* *}$ & $(0.0036)^{*}$ & $(0.0043)$ & $(0.0095)^{* *}$ \\
\hline Iyear_1997 & 0.0136 & 0.0614 & 0.0193 & 0.0100 & 0.0060 & 0.0276 \\
\hline & $(0.0040)^{* * *}$ & $(0.0132)^{* * *}$ & $(0.0227)$ & $(0.0036)^{* * *}$ & $(0.0042)$ & $(0.0094)^{* * *}$ \\
\hline Iyear_1998 & 0.0245 & 0.0261 & 0.0481 & 0.0192 & 0.0004 & 0.0117 \\
\hline & $(0.0044)^{* * *}$ & $(0.0254)$ & $(0.0269)^{*}$ & $(0.0037)^{* * *}$ & $(0.0042)$ & $(0.0094)$ \\
\hline Iyear_1999 & 0.0067 & 0.0976 & 0.0841 & 0.0079 & 0.0010 & 0.0123 \\
\hline & $(0.0048)$ & $(0.0409)^{* *}$ & $(0.0229)^{* * *}$ & $(0.0037)^{* *}$ & $(0.0042)$ & $(0.0094)$ \\
\hline Iyear_2000 & 0.0054 & 0.0695 & 0.0389 & 0.0043 & 0.0013 & 0.0084 \\
\hline & $(0.0086)$ & $(0.0338)^{* *}$ & $(0.0180)^{* *}$ & $(0.0037)$ & $(0.0043)$ & $(0.0094)$ \\
\hline Constant & -0.0067 & -0.0170 & -0.0228 & -0.0056 & -0.0016 & -0.0130 \\
\hline & $(0.0027)^{* *}$ & $(0.0100)^{*}$ & $(0.0150)$ & $(0.0029)^{*}$ & $(0.0039)$ & $(0.0087)$ \\
\hline Observations & 2257 & 1338 & 1252 & 2256 & 1338 & 1252 \\
\hline R-squared & 0.09 & 0.06 & 0.06 & 0.14 & 0.43 & 0.27 \\
\hline Robust stand & -13 & &
\end{tabular}

Robust standard errors in parentheses

* significant at $10 \% ; * \star$ significant at $5 \%$; ** significant at $1 \%$ 
Table 7

\begin{tabular}{|c|c|c|c|c|c|c|}
\hline & \multicolumn{3}{|c|}{ OLS with robust standard errors } & \multicolumn{3}{|c|}{ Outlier robust regression } \\
\hline & $\Delta$ credit & $\Delta$ smtrade & $\triangle$ smcap & $\Delta$ credit & $\Delta$ dsmtrade & $\triangle$ smcap \\
\hline \multirow[t]{2}{*}{ Lagged Level } & 0.0099 & -0.0035 & -0.0591 & 0.0198 & 0.0500 & 0.0487 \\
\hline & $(0.0032)^{* * *}$ & $(0.0802)$ & $(0.0382)$ & $(0.0022)^{* * *}$ & $(0.0021)^{* * *}$ & $(0.0032)^{* * *}$ \\
\hline \multirow[t]{2}{*}{ polity2 } & -0.0003 & -0.0015 & -0.0012 & -0.0003 & -0.0001 & -0.0003 \\
\hline & $(0.0003)$ & $(0.0006)^{* *}$ & $(0.0007)^{*}$ & $(0.0002)^{* *}$ & $(0.0002)$ & $(0.0006)$ \\
\hline \multirow[t]{2}{*}{$(81-85) *$ polity } & 0.0001 & 0.0013 & 0.0025 & 0.0004 & 0.0003 & 0.0009 \\
\hline & $(0.0003)$ & $(0.0007)^{*}$ & $(0.0011)^{* *}$ & $(0.0002)^{*}$ & $(0.0003)$ & $(0.0007)$ \\
\hline \multirow[t]{2}{*}{$(86-90) *$ polity } & 0.0009 & 0.0006 & 0.0008 & 0.0005 & -0.0000 & 0.0003 \\
\hline & $(0.0005)^{*}$ & $(0.0005)$ & $(0.0007)$ & $(0.0002)^{* *}$ & $(0.0003)$ & $(0.0007)$ \\
\hline \multirow[t]{2}{*}{$(91-95) *$ polity } & 0.0004 & 0.0018 & 0.0014 & -0.0001 & 0.0002 & -0.0004 \\
\hline & $(0.0004)$ & $(0.0008)^{* *}$ & $(0.0012)$ & $(0.0002)$ & $(0.0003)$ & $(0.0007)$ \\
\hline \multirow[t]{2}{*}{$(96-00) *$ polity } & 0.0011 & 0.0059 & 0.0051 & 0.0009 & 0.0002 & 0.0014 \\
\hline & $(0.0005)^{* *}$ & $(0.0014)^{* * *}$ & $(0.0013)^{* * *}$ & $(0.0002)^{* * *}$ & $(0.0003)$ & $(0.0007)^{* *}$ \\
\hline \multirow[t]{2}{*}{ durability } & 0.0001 & 0.0006 & 0.0006 & 0.0000 & 0.0000 & 0.0001 \\
\hline & $(0.0000)^{* *}$ & $(0.0002)^{* *}$ & $(0.0002)^{* * *}$ & $(0.0000)$ & $(0.0000)^{* *}$ & $(0.0000)^{*}$ \\
\hline \multirow[t]{2}{*}{ trade } & 0.0023 & -0.0158 & 0.0304 & 0.0006 & -0.0007 & -0.0229 \\
\hline & $(0.0023)$ & $(0.0067)^{* *}$ & $(0.0223)$ & $(0.0019)$ & $(0.0014)$ & $(0.0037)^{* * *}$ \\
\hline \multirow[t]{2}{*}{ Lbankcris } & -0.0075 & -0.0152 & -0.0230 & -0.0074 & 0.0002 & -0.0098 \\
\hline & $(0.0033)^{* *}$ & $(0.0090)^{*}$ & $(0.0092)^{* *}$ & $(0.0014)^{* * *}$ & $(0.0013)$ & $(0.0030)^{* * *}$ \\
\hline \multirow[t]{2}{*}{ Lgdpgrowth } & 0.0010 & -0.0020 & -0.0000 & 0.0009 & -0.0002 & 0.0001 \\
\hline & $(0.0003)^{* * *}$ & $(0.0011)^{*}$ & $(0.0015)$ & $(0.0001)^{* * *}$ & $(0.0001)$ & $(0.0003)$ \\
\hline \multirow[t]{2}{*}{ Ilegor_2 } & -0.0007 & 0.0068 & -0.0027 & -0.0013 & -0.0009 & 0.0074 \\
\hline & $(0.0018)$ & $(0.0084)$ & $(0.0122)$ & $(0.0011)$ & $(0.0011)$ & $(0.0025)^{* * *}$ \\
\hline \multirow[t]{2}{*}{ Ilegor_5 } & 0.0269 & 0.0715 & 0.0277 & 0.0100 & 0.0605 & 0.0249 \\
\hline & $(0.0089)^{* * *}$ & $(0.0108)^{* * *}$ & $(0.0146)^{*}$ & $(0.0057)^{*}$ & $(0.0062)^{* * *}$ & $(0.0147)^{*}$ \\
\hline \multirow[t]{2}{*}{ Iyear_1976 } & 0.0000 & 0.0000 & 0.0000 & 0.0000 & 0.0000 & 0.0000 \\
\hline & $(0.0000)$ & $(0.0000)$ & $(0.0000)$ & $(0.0000)$ & $(0.0000)$ & $(0.0000)$ \\
\hline \multirow[t]{2}{*}{ Iyear_1977 } & 0.0031 & 0.0043 & -0.0023 & 0.0053 & -0.0016 & 0.0001 \\
\hline & $(0.0028)$ & $(0.0047)$ & $(0.0091)$ & $(0.0038)$ & $(0.0049)$ & $(0.0120)$ \\
\hline \multirow[t]{2}{*}{ Iyear_1978 } & 0.0133 & 0.0034 & 0.0000 & 0.0100 & 0.0042 & 0.0000 \\
\hline & $(0.0037)^{* * *}$ & $(0.0114)$ & $(0.0000)$ & $(0.0038)^{* * *}$ & $(0.0048)$ & $(0.0000)$ \\
\hline \multirow[t]{2}{*}{ Iyear_1979 } & 0.0096 & -0.0023 & 0.0146 & 0.0033 & 0.0003 & 0.0063 \\
\hline & $(0.0050)^{*}$ & $(0.0066)$ & $(0.0072)^{* *}$ & $(0.0038)$ & $(0.0048)$ & $(0.0109)$ \\
\hline \multirow[t]{2}{*}{ Iyear_1980 } & 0.0021 & 0.0135 & 0.0163 & 0.0033 & 0.0029 & 0.0050 \\
\hline & $(0.0035)$ & $(0.0077)^{*}$ & $(0.0087)^{*}$ & $(0.0038)$ & $(0.0048)$ & $(0.0109)$ \\
\hline \multirow[t]{2}{*}{ Iyear_1981 } & 0.0116 & 0.0007 & -0.0007 & 0.0086 & -0.0014 & -0.0005 \\
\hline & $(0.0036)^{* * *}$ & $(0.0088)$ & $(0.0083)$ & $(0.0038)^{* *}$ & $(0.0049)$ & $(0.0114)$ \\
\hline Iyear_1982 & 0.0154 & -0.0166 & 0.0026 & 0.0072 & -0.0030 & -0.0039 \\
\hline & $(0.0040)^{* * *}$ & $(0.0128)$ & $(0.0098)$ & $(0.0038)^{*}$ & $(0.0049)$ & $(0.0110)$ \\
\hline Iyear_1983 & 0.0065 & 0.0066 & -0.0116 & 0.0054 & 0.0037 & 0.0086 \\
\hline & $(0.0034)^{*}$ & $(0.0096)$ & $(0.0211)$ & $(0.0037)$ & $(0.0049)$ & $(0.0110)$ \\
\hline Iyear_1984 & -0.0070 & -0.0171 & -0.0071 & -0.0012 & -0.0007 & 0.0085 \\
\hline & $(0.0050)$ & $(0.0124)$ & $(0.0169)$ & $(0.0037)$ & $(0.0049)$ & $(0.0109)$ \\
\hline Iyear_1985 & -0.0031 & 0.0182 & 0.0287 & 0.0006 & 0.0062 & 0.0158 \\
\hline & $(0.0040)$ & $(0.0123)$ & $(0.0164)^{*}$ & $(0.0037)$ & $(0.0049)$ & $(0.0109)$ \\
\hline Iyear_1986 & 0.0058 & 0.0220 & 0.0557 & 0.0041 & 0.0124 & 0.0251 \\
\hline & $(0.0051)$ & $(0.0100)^{* *}$ & $(0.0219)^{* *}$ & $(0.0037)$ & $(0.0048)^{* *}$ & $(0.0109)^{* *}$ \\
\hline Iyear_1987 & 0.0003 & 0.0349 & 0.0498 & 0.0034 & 0.0049 & 0.0154 \\
\hline & $(0.0051)$ & $(0.0124)^{* * *}$ & $(0.0277)^{*}$ & $(0.0037)$ & $(0.0048)$ & $(0.0109)$ \\
\hline Iyear 1988 & -0.0002 & -0.0139 & 0.0328 & 0.0028 & -0.0052 & 0.0117 \\
\hline
\end{tabular}




\begin{tabular}{|l|l|l|l|l|l|l|}
\hline & $(0.0046)$ & $(0.0126)$ & $(0.0206)$ & $(0.0037)$ & $(0.0048)$ & $(0.0108)$ \\
\hline Iyear_1989 & 0.0053 & 0.0248 & 0.0150 & 0.0058 & 0.0064 & 0.0289 \\
\hline & $(0.0050)$ & $(0.0130)^{*}$ & $(0.0322)$ & $(0.0037)$ & $(0.0048)$ & $(0.0108)^{* * *}$ \\
\hline Iyear_1990 & 0.0016 & -0.0257 & -0.0490 & 0.0028 & -0.0044 & -0.0033 \\
\hline & $(0.0040)$ & $(0.0152)^{*}$ & $(0.0409)$ & $(0.0037)$ & $(0.0048)$ & $(0.0108)$ \\
\hline Iyear_1991 & 0.0013 & -0.0112 & 0.0055 & 0.0017 & 0.0016 & 0.0091 \\
\hline & $(0.0039)$ & $(0.0103)$ & $(0.0121)$ & $(0.0037)$ & $(0.0048)$ & $(0.0107)$ \\
\hline Iyear_1992 & 0.0028 & 0.0021 & 0.0227 & 0.0049 & 0.0004 & 0.0091 \\
\hline & $(0.0042)$ & $(0.0125)$ & $(0.0167)$ & $(0.0037)$ & $(0.0047)$ & $(0.0107)$ \\
\hline Iyear_1993 & 0.0019 & 0.0803 & 0.0919 & 0.0048 & 0.0112 & 0.0376 \\
\hline & $(0.0042)$ & $(0.0367)^{* *}$ & $(0.0252)^{* * *}$ & $(0.0037)$ & $(0.0047)^{* *}$ & $(0.0106)^{* * *}$ \\
\hline Iyear_1994 & -0.0055 & 0.0035 & 0.0661 & -0.0007 & 0.0099 & 0.0369 \\
\hline & $(0.0039)$ & $(0.0156)$ & $(0.0194)^{* * *}$ & $(0.0037)$ & $(0.0047)^{* *}$ & $(0.0105)^{* * *}$ \\
\hline Iyear_1995 & 0.0035 & -0.0204 & 0.0110 & 0.0062 & -0.0060 & 0.0106 \\
\hline & $(0.0043)$ & $(0.0172)$ & $(0.0124)$ & $(0.0037)^{*}$ & $(0.0046)$ & $(0.0105)$ \\
\hline Iyear_1996 & 0.0064 & -0.0002 & 0.0226 & 0.0034 & 0.0033 & 0.0150 \\
\hline & $(0.0043)$ & $(0.0197)$ & $(0.0238)$ & $(0.0037)$ & $(0.0046)$ & $(0.0104)$ \\
\hline Iyear_1997 & 0.0106 & 0.0264 & -0.0117 & 0.0075 & 0.0049 & 0.0182 \\
\hline & $(0.0042)^{* *}$ & $(0.0129)^{* *}$ & $(0.0222)$ & $(0.0037)^{* *}$ & $(0.0046)$ & $(0.0104)^{*}$ \\
\hline Iyear_1998 & 0.0214 & -0.0093 & 0.0163 & 0.0163 & -0.0008 & 0.0032 \\
\hline & $(0.0045)^{* * *}$ & $(0.0244)$ & $(0.0241)$ & $(0.0037)^{* * *}$ & $(0.0046)$ & $(0.0104)$ \\
\hline Iyear_1999 & 0.0035 & 0.0615 & 0.0519 & 0.0050 & -0.0003 & 0.0044 \\
\hline & $(0.0045)$ & $(0.0390)$ & $(0.0188)^{* * *}$ & $(0.0037)$ & $(0.0046)$ & $(0.0104)$ \\
\hline Iyear_2000 & 0.0021 & 0.0338 & 0.0063 & 0.0020 & -0.0001 & -0.0006 \\
\hline & $(0.0077)$ & $(0.0321)$ & $(0.0169)$ & $(0.0038)$ & $(0.0047)$ & $(0.0104)$ \\
\hline Constant & -0.0055 & -0.0018 & -0.0063 & -0.0053 & 0.0001 & -0.0102 \\
\hline & $(0.0027)^{* *}$ & $(0.0083)$ & $(0.0157)$ & $(0.0029)^{*}$ & $(0.0042)$ & $(0.0095)$ \\
\hline Observations & 2257 & 1338 & 1252 & 2257 & 1338 & 1252 \\
\hline R-squared & 0.09 & 0.07 & 0.07 & 0.14 & 0.43 & 0.28 \\
\hline & 190756 & &
\end{tabular}

Robust standard errors in parentheses

significant at $10 \% ; * \star$ significant at $5 \% ; * \star *$ significant at $1 \%$

\section{Table 8}

Pair-wise correlations for levels of financial development

\begin{tabular}{|l|llllll|}
\hline & credit & smtrade & smcap & polity2 & Durability Herfindahl \\
\hline credit & 1.0000 & & & & & \\
\hline smtrade & 0.4748 & 1.0000 & & & & \\
\hline sm cap & 0.5317 & 0.4951 & 1.0000 & & & \\
\hline Polity2 & $\mathbf{0 . 3 9 2 7}$ & 0.1039 & 0.1619 & 1.0000 & & \\
\hline Durability & $\mathbf{0 . 4 5 1 1}$ & 0.1625 & $\mathbf{0 . 3 7 7 7}$ & 0.2293 & 1.0000 & \\
\hline Herfindahl & -0.2378 & -0.0192 & -0.0600 & -0.6322 & -0.1363 & 1.0000 \\
\hline
\end{tabular}




\section{Table 9}

Panel Logit results for whether stock market capitalisation is observed

\begin{tabular}{|l|l|l|}
\hline & Coefficient & Standard Error \\
\hline Polity & $\mathbf{. 2 4 6 6 6 1 7} * * *$ & $\mathbf{. 0 1 8 3 4 1 9}$ \\
\hline Durability & $\mathbf{. 1 2 4 5 3 8 3} * * *$ & $\mathbf{. 0 0 8 1 6 7 3}$ \\
\hline $\begin{array}{l}\text { GDP per capita } \\
1970\end{array}$ & $-.0000698 * * *$ & .0000146 \\
\hline $\begin{array}{l}\text { Trade } \\
\text { openness }\end{array}$ & $-.0078911 * * *$ & .0022073 \\
\hline Constant & $-4.30371 * * *$ & .314169 \\
\hline
\end{tabular}

Table 10

Panel Tobit results for limited dependent variable SMCAP

\begin{tabular}{|l|l|l|}
\hline & Coefficient & Standard Error \\
\hline Polity & $.0326142 * * *$ & .0049437 \\
\hline Durability & $.0111681^{* * *}$ & .0013551 \\
\hline L.bank crisis & $.2298538^{* * *}$ & .0805943 \\
\hline L.GDP growth & $.021792 * * *$ & .0074284 \\
\hline trade & $-.0039464 * * *$ & .0009054 \\
\hline Civil Law & $-.9258388^{* * *}$ & .0939532 \\
\hline Socialist Law & $-3.504303 * * *$ & .2762773 \\
\hline Constant & $-12.77935 * * *$ & .2008821 \\
\hline \# of observations: 2648 & $\begin{array}{l}1396 \text { left-censored } \\
\text { observations }\end{array}$ & \\
\hline
\end{tabular}

(Year dummies included but coefficients not reported)

\section{Table 11}

Panel Tobit results for limited dependent variable SMTRADE

\begin{tabular}{|l|l|l|}
\hline & Coefficient & Standard Error \\
\hline Polity & $.0890944^{* * *}$ & .006755 \\
\hline Durability & $.0146644^{* * *}$ & .0013064 \\
\hline L.bank crisis & $.2169186^{* * *}$ & .0779959 \\
\hline L.GDP growth & .0086983 & .0064918 \\
\hline trade & $-.0037966^{* * *}$ & .0009041 \\
\hline Civil Law & $-.3408615^{* * *}$ & .0885858 \\
\hline Socialist Law & $-1.837788^{* * *}$ & .2425709 \\
\hline Constant & -3.427124 & .1728336 \\
\hline \# of observations: 2675 & $\begin{array}{l}1337 \text { left-censored } \\
\text { observations }\end{array}$ & \\
\hline
\end{tabular}

(Year dummies included but coefficients not reported) 


\section{Appendix}

Table A

Political regimes and financial development:

GMM estimates

\begin{tabular}{|c|c|c|c|}
\hline & $\Delta$ credit & $\Delta$ deposits & $\Delta$ smcap \\
\hline \multirow[t]{2}{*}{ polity2 } & 0.0005 & 0.0004 & 0.0009 \\
\hline & $(0.0001)^{* * *}$ & $(0.0001)^{* * *}$ & $(0.0004)^{* *}$ \\
\hline \multirow[t]{2}{*}{ durability } & 0.0001 & 0.0001 & 0.0004 \\
\hline & $(0.0000)^{* * *}$ & $(0.0000)^{*}$ & $(0.0001)^{* * *}$ \\
\hline \multirow[t]{2}{*}{ trade } & 0.0036 & 0.0297 & -0.0009 \\
\hline & $(0.0023)$ & $(0.0070)^{* * *}$ & $(0.0043)$ \\
\hline \multirow[t]{2}{*}{ Lbankcris } & -0.0078 & -0.0001 & -0.0203 \\
\hline & $(0.0033)^{* *}$ & $(0.0027)$ & $(0.0088)^{* *}$ \\
\hline \multirow[t]{2}{*}{ Lgdpgrowth } & 0.0011 & 0.0009 & -0.0006 \\
\hline & $(0.0003)^{* * *}$ & $(0.0003)^{* * *}$ & $(0.0017)$ \\
\hline \multirow[t]{2}{*}{ Civil Law } & 0.0008 & 0.0011 & 0.0068 \\
\hline & $(0.0019)$ & $(0.0019)$ & $(0.0080)$ \\
\hline \multirow[t]{2}{*}{ Socialist Law } & 0.0305 & 0.0481 & 0.0516 \\
\hline & $(0.0077)^{* * *}$ & $(0.0175)^{* * *}$ & $(0.1521)$ \\
\hline \multirow[t]{2}{*}{ year $==1976$} & 0.0000 & 0.0000 & 0.0000 \\
\hline & $(0.0000)$ & $(0.0000)$ & $(0.0000)$ \\
\hline \multirow[t]{2}{*}{ year $==1977$} & -0.0037 & 0.0020 & 0.0466 \\
\hline & $(0.0050)$ & $(0.0044)$ & $(0.0461)$ \\
\hline \multirow[t]{2}{*}{ year $==1978$} & 0.0064 & 0.0017 & 0.0481 \\
\hline & $(0.0056)$ & $(0.0047)$ & $(0.0435)$ \\
\hline \multirow[t]{2}{*}{ year $==1979$} & 0.0029 & -0.0079 & 0.0643 \\
\hline & $(0.0070)$ & $(0.0059)$ & $(0.0445)$ \\
\hline \multirow[t]{2}{*}{ year $==1980$} & -0.0048 & -0.0096 & 0.0685 \\
\hline & $(0.0057)$ & $(0.0053)^{*}$ & $(0.0453)$ \\
\hline \multirow[t]{2}{*}{ year $==1981$} & 0.0051 & 0.0059 & 0.0615 \\
\hline & $(0.0052)$ & $(0.0059)$ & $(0.0442)$ \\
\hline \multirow[t]{2}{*}{ year $==1982$} & 0.0088 & 0.0090 & 0.0638 \\
\hline & $(0.0058)$ & $(0.0065)$ & $(0.0463)$ \\
\hline \multirow[t]{2}{*}{ year $==1983$} & 0.0003 & 0.0024 & 0.0473 \\
\hline & $(0.0053)$ & $(0.0049)$ & $(0.0480)$ \\
\hline \multirow[t]{2}{*}{ year $==1984$} & -0.0127 & -0.0040 & 0.0533 \\
\hline & $(0.0059)^{* *}$ & $(0.0052)$ & $(0.0490)$ \\
\hline \multirow[t]{2}{*}{ year $==1985$} & -0.0095 & -0.0035 & 0.0911 \\
\hline & $(0.0040)^{* *}$ & $(0.0044)$ & $(0.0605)$ \\
\hline \multirow[t]{2}{*}{ year $==1986$} & 0.0000 & 0.0000 & 0.1077 \\
\hline & $(0.0000)$ & $(0.0000)$ & $(0.0615)^{*}$ \\
\hline \multirow[t]{2}{*}{ year $==1987$} & -0.0048 & -0.0032 & 0.0998 \\
\hline & $(0.0055)$ & $(0.0058)$ & $(0.0662)$ \\
\hline \multirow[t]{2}{*}{ year $==1988$} & -0.0060 & -0.0052 & 0.0808 \\
\hline & $(0.0056)$ & $(0.0058)$ & $(0.0561)$ \\
\hline \multirow[t]{2}{*}{ year $==1989$} & 0.0001 & -0.0066 & 0.0633 \\
\hline & $(0.0065)$ & $(0.0056)$ & $(0.0162)^{* * *}$ \\
\hline \multirow[t]{2}{*}{ year $==1990$} & -0.0033 & -0.0124 & 0.0000 \\
\hline & $(0.0051)$ & $(0.0054)^{* *}$ & $(0.0000)$ \\
\hline \multirow[t]{2}{*}{ year==1991 } & -0.0047 & -0.0043 & 0.0594 \\
\hline & $(0.0053)$ & $(0.0057)$ & $(0.0434)$ \\
\hline
\end{tabular}




\begin{tabular}{|l|l|l|l|}
\hline year $==1992$ & -0.0031 & -0.0001 & 0.0756 \\
\hline year==1993 & $(0.0060)$ & $(0.0050)$ & $(0.0422)^{*}$ \\
\hline & -0.0040 & 0.0012 & 0.1428 \\
\hline year==1994 & $(0.0061)$ & $(0.0058)$ & $(0.0490)^{* * *}$ \\
\hline & -0.0115 & -0.0067 & 0.1130 \\
\hline year==1995 & $(0.0054)^{* *}$ & $(0.0048)$ & $(0.0492)^{* *}$ \\
\hline & -0.0029 & -0.0083 & 0.0576 \\
\hline year==1996 & $(0.0053)$ & $(0.0047)^{*}$ & $(0.0476)$ \\
\hline & 0.0026 & -0.0015 & 0.0904 \\
\hline year==1997 & $(0.0056)$ & $(0.0060)$ & $(0.0497)^{*}$ \\
\hline & 0.0066 & 0.0024 & 0.0555 \\
\hline year==1998 & $(0.0053)$ & $(0.0051)$ & $(0.0519)$ \\
\hline & 0.0176 & 0.0079 & 0.0860 \\
\hline year==1999 & $(0.0055)^{* * *}$ & $(0.0050)$ & $(0.0497)^{*}$ \\
\hline year==2000 & 0.0008 & 0.0149 & 0.1213 \\
\hline & $(0.0069)$ & $(0.0096)$ & $(0.0452)^{* * *}$ \\
\hline Constant & -0.0004 & 0.0116 & 0.0696 \\
\hline & $(0.0098)$ & $(0.0121)$ & $(0.0461)$ \\
\hline $\begin{array}{l}\text { Hansen's J-test (p- } \\
\text { value) }\end{array}$ & 0.0005 & -0.0037 & -0.0698 \\
\hline $\begin{array}{l}\text { First-stage R-squared } \\
\text { value }\end{array}$ & $0.0051)$ & $(0.0051)$ & $(0.0378)^{*}$ \\
\hline $\begin{array}{l}\text { Hausman test of } \\
\text { exogeneity (p-value) }\end{array}$ & 0.8729 & 0.3020 & 0.7265 \\
\hline Observations & 1 & 0.8739 & 0.8649 \\
\hline
\end{tabular}

Notes:

1. The null hypothesis of the Hansen's J-test states that the instruments used in the GMM estimations are valid

2. The tests of exogeneity is a Hausman test which examines the null hypothesis that there is no statistically significant difference between the OLS and GMM estimates. The null hypothesis states that Polity 2 is exogenous

3. significant at $10 \% ; * *$ significant at $5 \% ; * * *$ significant at $1 \%$ 